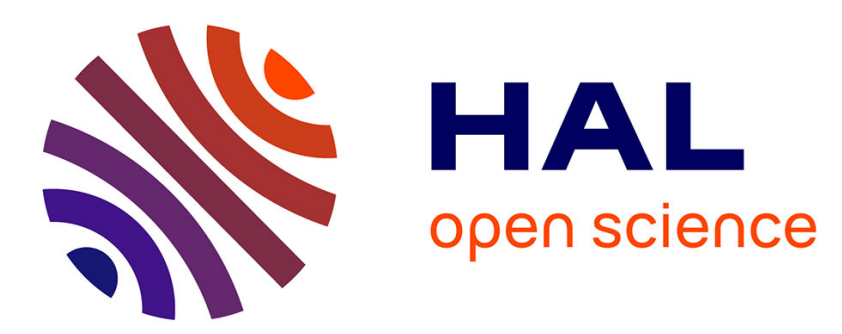

\title{
The response of marine carbon and nutrient cycles to ocean acidification: Large uncertainties related to phytoplankton physiological assumptions
}

\author{
Alessandro Tagliabue, Laurent Bopp, Marion Gehlen
}

\section{To cite this version:}

Alessandro Tagliabue, Laurent Bopp, Marion Gehlen. The response of marine carbon and nutrient cycles to ocean acidification: Large uncertainties related to phytoplankton physiological assumptions. Global Biogeochemical Cycles, 2011, 25 (3), pp.GB3017. 10.1029/2010GB003929 . hal-03113011

\author{
HAL Id: hal-03113011 \\ https://hal.science/hal-03113011
}

Submitted on 6 May 2021

HAL is a multi-disciplinary open access archive for the deposit and dissemination of scientific research documents, whether they are published or not. The documents may come from teaching and research institutions in France or abroad, or from public or private research centers.
L'archive ouverte pluridisciplinaire HAL, est destinée au dépôt et à la diffusion de documents scientifiques de niveau recherche, publiés ou non, émanant des établissements d'enseignement et de recherche français ou étrangers, des laboratoires publics ou privés. 


\title{
The response of marine carbon and nutrient cycles to ocean acidification: Large uncertainties related to phytoplankton physiological assumptions
}

\begin{abstract}
Alessandro Tagliabue, ${ }^{1}$ Laurent Bopp, ${ }^{1}$ and Marion Gehlen ${ }^{1}$
Received 26 July 2010; revised 22 February 2011; accepted 9 June 2011; published 25 August 2011.

[1] Alongside climate change, anthropogenic emissions of $\mathrm{CO}_{2}$ will cause ocean acidification (OA), which will impact upon key biogeochemical processes in the ocean such as net primary production (NPP), carbon export (CEX), $\mathrm{N}_{2}$ fixation (NFIX), denitrification (DENIT), and ocean suboxia (SOX). However, appraising the impact of $\mathrm{OA}$ on marine biogeochemical cycles requires ocean general circulation and biogeochemistry models (OGCBMs) that necessitate a number of assumptions regarding the response of phytoplankton physiological processes to OA. Of particular importance are changes in C:N:P stoichiometry, which cannot be accounted for in current generation OGCBMs that rely on fixed Redfield C:N:P ratios. We developed a new version of the PISCES OGCBM that resolves the cycles of $\mathrm{C}, \mathrm{N}$, and $\mathrm{P}$ independently to investigate the impact of assumptions that OA (1) enhances NPP, (2) enhances losses of fixed carbon in dissolved organic forms, and (3) modifies the uptake of nutrients by phytoplankton. In total, six simulations were performed over the period 1860-2100. We find that while the prescribed " $\mathrm{CO}_{2}$ sensitivity" of rate processes explains the NPP response, there are large uncertainties in the response of CEX, NFIX, DENIT, and SOX related to assumptions regarding the fate of fixed carbon and nutrient uptake. The overall responses of NPP and CEX are opposite and of similar magnitude to those predicted to occur from climate change alone, suggesting that changes in stoichiometry and NPP in response to OA (and probably also climate change) need to be evaluated in non-Redfield coupled-climate OGCBMs. Using a recent synthesis of OA experiments, it was not possible to evaluate whether one or more of our scenarios was most likely. Future coupled experimental modeling approaches are necessary to better understand the impact of OA on ocean biogeochemistry.
\end{abstract}

Citation: Tagliabue, A., L. Bopp, and M. Gehlen (2011), The response of marine carbon and nutrient cycles to ocean acidification: Large uncertainties related to phytoplankton physiological assumptions, Global Biogeochem. Cycles, 25, GB3017, doi:10.1029/2010GB003929.

\section{Introduction}

[2] The increases in atmospheric $\mathrm{CO}_{2}\left(\mathrm{CO}_{2 \mathrm{~atm}}\right)$ concentrations recorded since the industrial revolution are predicted to continue over the coming century and will likely have profound impacts on the Earth's climate [Denman et al., 2007]. In this context, the ocean is a key regulator of $\mathrm{CO}_{2 \mathrm{~atm}}$ concentrations that takes up one quarter of anthropogenic $\mathrm{CO}_{2}$ emissions and air-sea $\mathrm{CO}_{2}$ exchange will respond to both a changing air-sea $\mathrm{CO}_{2}$ gradient and any associated climate change [e.g., Le Quéré et al., 2009]. Modifications to climate will also impact key biogeochemical processes in the ocean, such as net primary productivity (NPP), the export of

\footnotetext{
${ }^{1}$ Laboratoire des Sciences du Climat et de l'Environnement, IPSLCEA-CNRS-UVSQ Orme des Merisiers, Gif sur Yvette, France.

Copyright 2011 by the American Geophysical Union. 0886-6236/11/2010GB003929
}

organic carbon to the ocean interior (CEX, which is responsible for maintaining the ocean's vertical dissolved inorganic carbon (DIC) gradient) and the cycling of oxygen and nutritive elements (nitrogen, phosphorous, silicic acid and iron). Recent studies by state-of-the-art coupled-climate models suggest that climate change will reduce oceanic NPP and CEX by $7-13 \%$ and $6-20 \%$, respectively, by 2100 [Steinacher et al., 2010] primarily due to the lesser vertical nutrient supply that results from climate-induced changes to stratification (similar to earlier studies [e.g., Bopp et al., 2001, 2005]).

[3] Ocean biogeochemistry will not only be impacted by climate change over the coming century, but also by progressive ocean "acidification" (OA). As $\mathrm{CO}_{2 \mathrm{~atm}}$ rises, the absolute uptake of $\mathrm{CO}_{2}$ by the ocean will increase and, as a result of oceanic carbon chemistry, the $\mathrm{pH}$ will decline, i.e., become more acidic [Zeebe and Wolf-Gladrow, 2001]. This process is ongoing, with ocean $\mathrm{pH}$ already having declined by $\sim 0.1 \mathrm{pH}$ units or a $30 \%$ increase in the concentration of 


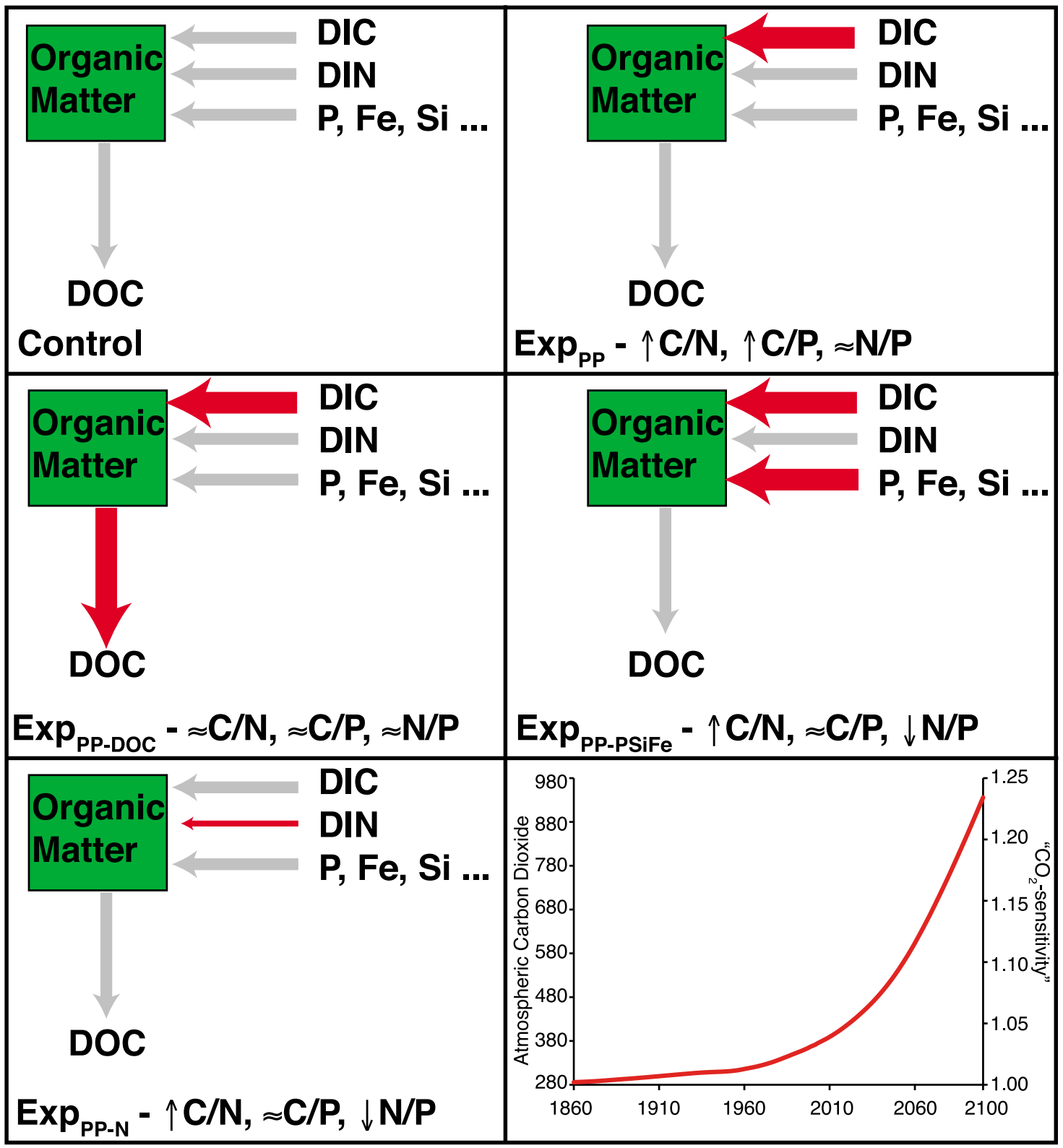

Figure 1. A schematic representation of the simulations conducted in this study, with a focus on the changes to the transport of DIC, DIN, $\mathrm{P}, \mathrm{Fe}, \mathrm{Si}$, the production of DOC, and the associated changes to $\mathrm{C} / \mathrm{N}, \mathrm{C} / \mathrm{P}$, and $\mathrm{N} / \mathrm{P}$ ratios. In the bottom right panel we present the evolution of atmospheric $\mathrm{CO}_{2}$ and the " $\mathrm{CO}_{2}$ sensitivity" (that impacts the rate processes illuminated by red arrows in the other panels) between 1860 and 2100 .

$\mathrm{H}^{+}$ions [Caldeira and Wickett, 2003]. Modeling studies suggest potential declines in mean surface $\mathrm{pH}$ of $0.3-0.4 \mathrm{pH}$ units by 2100 [e.g., Orr et al., 2005], which have the potential to dramatically alter ocean biogeochemical cycles [e.g., Finkel et al., 2010; Hutchins et al., 2009; Riebesell et al., 2009]. Leaving aside the potential impact of OA on calcifying marine organisms [e.g., Fabry, 2008; Ridgwell et al., 2009 and references therein], a number of $\mathrm{CO}_{2}$ perturbation experiments have suggested $\mathrm{CO}_{2 \mathrm{~atm}}$ impacts on the biology of noncalcifiers. For example, the consumption of DIC during photosynthesis has been shown to increase with rising $\mathrm{CO}_{2}$ levels [e.g., Raven and Johnston, 1991; Riebesell et al., 1993; Hein and Sand-Jensen, 1997; Gordillo et al.,
2003; Hutchins et al., 2007; Riebesell et al., 2007], as has the fixation of $\mathrm{N}_{2}$ by diazotrophs [e.g., Hutchins et al., 2007; Barcelos e Ramos et al., 2007; Levitan et al., 2007], although nutrient limitation effects can also be important [e.g., Gordillo et al., 2003; Fu et al., 2008]. One recent laboratory study suggests OA might reduce Fe bioavailability [Shi et al., 2010], while a mesocosm experiment showed the opposite response [Breitbarth et al., 2010]. There is little evidence of impacts on $\mathrm{P}$ cycling in the very few studies that have been performed thus far [e.g., Fu et al., 2007; Tanaka et al., 2008], with similarly inconclusive results for silicic acid (Si) [Milligan et al., 2004; Bellerby et al., 2008]. Finally, changes to the composition of the phytoplankton in response to OA (as 
Table 1. A Summary of the Model Experiments That Describe if There is a Change in Atmospheric $\mathrm{CO}_{2}$, Which Element's Biotic Uptake is Impacted, if the C/N, C/X, and N/P Ratios of Organic Matter Change (Relative to the Control), and Whether Increased C Uptake is Offset by Increased DOC Production ${ }^{\mathrm{a}}$

\begin{tabular}{lcccccc}
\hline \multicolumn{1}{c}{ Exp } & $\mathrm{CO}_{2}$ & Impact & $\mathrm{C} / \mathrm{N}$ & $\mathrm{C} / \mathrm{X}$ & $\mathrm{N} / \mathrm{P}$ & $\mathrm{DOC}$ \\
\hline $\mathrm{CTL}$ & No & None & No & No & No & No \\
$\mathrm{CO}_{2}-\mathrm{CTL}$ & $\mathrm{Yes}$ & None & No & No & No & No \\
Exp $_{\text {PP }}$ & Yes & $\mathrm{C}$ & + & + & No & No \\
ExpPP-DOC $_{\text {Yes }}$ & $\mathrm{C}$ & No & No & No & Yes \\
ExpPP-PSiFe & Yes & $\mathrm{C}, \mathrm{X}$ & + & No & - & No \\
ExpPP-N & Yes & $\mathrm{N}$ & + & No & - & No \\
\hline
\end{tabular}

"A "+" signifies that the ratio increased, while a "-" denotes a decrease in the given ratio. The letter $\mathrm{X}$ denotes $\mathrm{P}, \mathrm{Fe}$ and $\mathrm{Si}$. In all cases the rate process increases (or decreases for $\mathrm{N}$ uptake) at a $\mathrm{CO}_{2}$-sensitive rate $\left(0.002714 \mathrm{ppm} \mathrm{CO}_{2 \mathrm{~atm}}^{-1}\right)$ taken from the experiments of Riebesell et al. [2007].

well as climate change) could also impact the cycling of "taxon-specific" nutrients, such as Si for diatoms [e.g., Tortell et al., 2002, 2008].

[4] Importantly, there have also been a number of experimental studies that have suggested modifications to the stoichiometry of $\mathrm{C}$ to other nutrients (generally $\mathrm{N}$ and $\mathrm{P}$ ) in response to OA. Classically, the cycling of $\mathrm{C}, \mathrm{N}$ and $\mathrm{P}$ has been conceptually coupled by the "Redfield" ratio [Redfield, 1934] and most global models of ocean biogeochemistry consider that (aside from $\mathrm{N}_{2}$ fixers in some cases) the relative contribution of $\mathrm{C}, \mathrm{N}$ and $\mathrm{P}$ to organic matter remains constant [e.g., Aumont and Bopp, 2006; Moore and Doney, 2007]. In a mesocosm experiment, Riebesell et al. [2007] found significant increases in the $\mathrm{C} / \mathrm{N}$ uptake ratio due to additional $\mathrm{C}$ fixation in response to $\mathrm{OA}$ that could act as a negative feedback on climate change. Other studies of natural populations, as well as culture experiments suggest modifications to the $\mathrm{C} / \mathrm{N}$ and $\mathrm{N} / \mathrm{P}$ ratio of organic matter in response to OA are likely, but that their nature is complex [Hutchins et al., 2009; Finkel et al., 2010]. Moreover, floristic shifts in phytoplankton with species-specific C/N/P ratios [e.g., Arrigo et al., 1999; Mills and Arrigo, 2010] in response to OA might also be important [e.g., Feng et al., 2010].

[5] Assessing the impact of OA on ocean biogeochemistry necessitates the use of global ocean general circulation and biogeochemical models (OGCBMs) that resolve the relevant biogeochemical cycles and processes in a prognostic fashion. Since all coupled-climate OGCBMs assume "Redfield" stoichiometry for organic matter, climate or $\mathrm{CO}_{2 \mathrm{~atm}}$ induced variability in $\mathrm{C} / \mathrm{N} / \mathrm{P}$ ratios are not considered when estimates are made of NPP and CEX over the coming century [Steinacher et al., 2010]. An early study by Schneider et al. [2004] suggested that $\mathrm{CO}_{2 \mathrm{~atm}}$ related changes to the $\mathrm{C} / \mathrm{N}$ ratio could act as a weak negative feedback on $\mathrm{CO}_{2 \mathrm{~atm}}(\sim 70 \mathrm{PgC})$, but biological production and remineralization were not treated explicitly. More recently, a climate coupled OGCBM study suggests that $\mathrm{CO}_{2}$-induced increases in the $\mathrm{C} / \mathrm{N}$ ratio are indeed a weak feedback on $\mathrm{CO}_{2 \mathrm{~atm}}$ (relative to the size of anthropogenic emissions), but large impacts on CEX and the cycling of $\mathrm{O}_{2}$ and $\mathrm{N}$ were found [Oschlies et al., 2008]. Cumulative CEX increased by over $100 \mathrm{Pg} \mathrm{C}$ and there was a $50 \%$ increase in the volume of suboxic water by 2100 [Oschlies et al., 2008]. However, estimating the impact of OA-induced changes in rates or stoichiometry in OGCBMs is not straightforward and requires various assumptions to be made. Most clear-cut is that $\mathrm{OA}$ enhances $\mathrm{CO}_{2}$ fixation, which raises $\mathrm{C} / \mathrm{N}$ uptake ratios and that these changes are preserved in sinking organic matter [Riebesell et al., 2007; Oschlies et al., 2008]. On the other hand, it is plausible that the additional fixed DIC is lost as dissolved organic carbon (DOC) with no change in particulate organic matter ratios, with increased production of so-called transparent exopolymer particles (TEPs) [Engel, 2002] able to enhance CEX by aggregation and coagulation of DOC [Riebesell et al., 2007; Arrigo, 2007]. In this case, spatial variability in bacterial limitation will be important in governing the turnover of any additional DOC [Thingstad et al., 2008] and the impact on CEX. Additionally, if additional DOC is subducted away from the sea surface, then the depth of remineralization to DIC will dictate its influence on air-sea $\mathrm{CO}_{2}$ exchange. Regardless of the fate of the extra DIC fixation, assumptions made about the transport into the phytoplankton cell (termed "uptake" hereafter) of other nutrients ( $\mathrm{P}, \mathrm{Si}$ and Fe) might also be important. If uptake of $\mathrm{P}, \mathrm{Si}$ and Fe were unchanged, then $\mathrm{C} / \mathrm{X}$ ratios (where $\mathrm{X}$ is either $\mathrm{P}, \mathrm{Si}$, or $\mathrm{Fe}$ ) of organic matter would rise alongside $\mathrm{C} / \mathrm{N}$ ratios, with $\mathrm{N} /$ $\mathrm{X}$ ratios unchanged. Conversely, if uptake of $\mathrm{P}, \mathrm{Si}$ and $\mathrm{Fe}$ were upregulated in response to $\mathrm{OA}, \mathrm{C} / \mathrm{X}$ ratios would remain unchanged in organic matter and decreasing $\mathrm{N} / \mathrm{X}$ ratios would accompany the change in $\mathrm{C} / \mathrm{N}$ ratios. Finally, modifications to N/P ratios could result from changes to the uptake of $\mathrm{N}$ or $\mathrm{P}$. Assessing these factors requires multinutrient OGCBMs that are able to decouple the cycles of $\mathrm{N}$ and $\mathrm{P}$ from $\mathrm{C}$ in dissolved/particulate organic and inorganic pools, with most global OGCBMs unable to respond to these questions [e.g., Anderson and Mitra, 2010].

[6] In this study, we modified the PISCES OGCBM to treat the cycling of $\mathrm{N}$ and $\mathrm{P}$ independent of $\mathrm{C}$ in all organic and inorganic pools and examined the impact of $\mathrm{OA}$-induced changes to $\mathrm{C}$ fixation, the loss of fixed carbon as DOC, as well as modifications to the uptake of other nutritive elements between 1860 and 2100. Specifically, we conducted four model experiments: (1) the $\mathrm{C}$ fixation rate and thus $\mathrm{C} / \mathrm{N}$ ratio of organic matter increases with $\mathrm{CO}_{2 \mathrm{~atm}}$ via enhanced $\mathrm{C}$ fixation, but the uptake of $\mathrm{P}, \mathrm{Si}$ and $\mathrm{Fe}$ was unchanged (raising $\mathrm{C} / \mathrm{X}$ and $\mathrm{C} / \mathrm{N}$, but leaving $\mathrm{N} / \mathrm{X}$ unchanged, Exp $\mathrm{PP}_{\mathrm{PP}}$ ); (2) the increase in $\mathrm{C}$ fixation with rising $\mathrm{CO}_{2 \mathrm{~atm}}$ is offset by increased exudation of DOC (Exp PP-DOC $_{2}$, resulting in no change to stoichiometry of sinking organic matter; (3) the C fixation rate and thus the $\mathrm{C} / \mathrm{N}$ ratio of organic matter increases with $\mathrm{CO}_{2 \mathrm{~atm}}$, as well as uptake of $\mathrm{P}, \mathrm{Si}$ and $\mathrm{Fe}$ (raising $\mathrm{C} / \mathrm{N}$, reducing $\mathrm{N} / \mathrm{X}$, but leaving $\mathrm{C} / \mathrm{X}$ unchanged, Exp PP-PSiFe $_{\text {); }}$ and (4) the $\mathrm{C} / \mathrm{N}$ ratio of organic matter increases with $\mathrm{CO}_{2 \mathrm{~atm}}$ via reduced $\mathrm{N}$ uptake, with no direct change to the uptake of $\mathrm{C}, \mathrm{P}, \mathrm{Si}$, or $\mathrm{Fe}$ (raising $\mathrm{C} / \mathrm{N}$, reducing $\mathrm{N} / \mathrm{X}$, but leaving $\mathrm{C} / \mathrm{X}$ unchanged, Exp $\mathrm{PP}_{\mathrm{N}}$ ). The model experiments are summarized in Figure 1 and Table 1 and two control experiments were also performed. With these experiments we can assess the impact of assuming (1) DOC losses also increase, (2) concomitant decreases to 
$\mathrm{N} / \mathrm{P}$ ratios, and (3) the processes behind N/P ratio decreases ( $\mathrm{N}$ or $\mathrm{P}$ uptake) on ocean biogeochemistry.

\section{Methods}

\subsection{PISCES-NP}

[7] The PISCES model simulates nanophytoplankton, diatoms, two size classes of organic matter that sink and are remineralized differentially, two zooplankton grazers, DIC, DOC, oxygen $\left(\mathrm{O}_{2}\right)$, nitrate $\left(\mathrm{NO}_{3}\right)$, ammonium $\left(\mathrm{NH}_{4}\right)$, phosphate $\left(\mathrm{PO}_{4}\right), \mathrm{Si}, \mathrm{Fe}$, and resolves the ocean carbon system chemistry (see Aumont and Bopp [2006] for a complete description). Like its contemporary OGCBMs, the standard version of PISCES rests on "Redfield" nutrient stoichiometry and "Monod" limitation of phytoplankton growth rates [Aumont and Bopp, 2006]. Therefore $\mathrm{N}$ and $\mathrm{P}$ concentrations in organic matter (phytoplankton, zooplankton, sinking particles, etc.) are not prognostically computed and transported by the model, but are assumed to exist in a constant ratio to $\mathrm{C}$ (the $\mathrm{C} / \mathrm{N} / \mathrm{P}$ ratio is $122 / 16 / 1$ [Takahashi et al., 1985]). While this is advantageous in some respects, it clearly precludes a full assessment of the potential impact of $\mathrm{CO}_{2}$-induced changes in organic matter stoichiometry, particularly in terms of the unconstrained impacts on other nutrients. Nevertheless, the standard PISCES model does include substantial variability in $\mathrm{C} / \mathrm{Fe}$ and $\mathrm{C} / \mathrm{Si}$ ratios as a function of the phytoplankton functional group (diatoms or nanophytoplankton) and environmental conditions (e.g., nutrient concentrations or light levels) and already treated $\mathrm{Fe}$ and Si independently [Aumont and Bopp, 2006]. For this study, we revised the PISCES model to treat the uptake, assimilation, sinking and remineralization of $\mathrm{N}$ and $\mathrm{P}$ independent of $\mathrm{C}$, which permits the model to prognostically compute the $\mathrm{N}$ and $\mathrm{P}$ content in all $\mathrm{C}$ pools. In total 14 additional tracers were added, including dissolved organic $\mathrm{N}$ and $\mathrm{P}$ (DON and DOP), which increases the total number of variables from 24 (standard PISCES) to 38 (PISCES-NP) to be transported by the physical model.

[8] The nutrient limitation philosophy of PISCES-NP is unchanged from that described by Aumont and Bopp [2006]. It assumes Monod limitation of growth, where a temperaturedependent maximum growth rate is scaled by a "light limitation" term and then by the most limiting nutrient (N, P, and $\mathrm{Fe}$, as well as $\mathrm{Si}$ for diatoms). Half-saturation constants are fixed for $\mathrm{NO}_{3}, \mathrm{NH}_{4}, \mathrm{PO}_{4}$ and $\mathrm{DOP}$ (which is assumed to be available to phytoplankton). On the other hand, the halfsaturation constant for $\mathrm{Fe}$ increases as a function of the total carbon biomass for each group. This is an attempt to account for the noted effect of cell size on phytoplankton affinity for Fe. Smaller cells are assumed to have lower half-saturation constants for $\mathrm{Fe}$ and vice versa [Blain et al., 2004; Timmermans et al., 2004]. In PISCES the assumption is made that greater biomass consists of larger cells, which would then have greater half-saturation constants for $\mathrm{Fe}$ (i.e., more $\mathrm{Fe}$ limited for a given $\mathrm{Fe}$ concentration). The half-saturation constant for $\mathrm{Si}$ limitation increases as a function of Si concentrations. Light limitation increases as $\mathrm{Chl} / \mathrm{C}$ ratios decline and as nutrient limitation increases. The light limitation term is modified by Fe stress, and light also modifies the $\mathrm{Fe}$ demand. Moreover, the $\mathrm{Si}$ demand (or the degree of silicification) is modulated by the degree of $\mathrm{Fe}$ stress such that diatoms are more silic- ified (have a greater $\mathrm{Si} / \mathrm{C}$ ratio) when $\mathrm{Fe}$ limited. However, there are no interactions between $\mathrm{N}$ and $\mathrm{P}$ limitation. These aspects of PISCES are retained for PISCES-NP (see Aumont and Bopp [2006] for full equations).

[9] The parameterization of $\mathrm{N}_{2}$ fixation has been modified from the original version of PISCES to treat $\mathrm{N}$ fixers as an implicit functional group. Our philosophy was to consider $\mathrm{N}_{2}$ fixation as a processes by which algae accumulate PON without the uptake of DIN, alongside $\mathrm{P}$ and Fe uptake and $\mathrm{C}$ fixation that occurs under certain conditions. As such, $\mathrm{N}_{2}$ fixation increases with light, temperature and decreases as $\mathrm{NO}_{3}$ increases and with increasing limitation by either $\mathrm{P}$ or $\mathrm{Fe}$. After $\mathrm{C}, \mathrm{P}$ and $\mathrm{Fe}$ are taken up from the dissolved pool during $\mathrm{N}_{2}$ fixation, they are assumed to follow the fate of $\mathrm{C}$, $\mathrm{N}, \mathrm{P}$ and $\mathrm{Fe}$ in the nanophytoplankton (grazing, mortality, sinking, remineralization etc.). Specifically, we take the temperature-dependent growth rate for the nanophytoplankton group, and this is scaled by limitation by light, temperature, $\mathrm{P}$ and $\mathrm{Fe}$, as well as $\mathrm{NO}_{3}$ concentrations to result in the realized rate of $\mathrm{N}_{2}$ fixation (moles $\mathrm{N}^{-1} \mathrm{~s}^{-1}$ ), with uptake of both $\mathrm{PO}_{4}$ and DOP via a N/P ratio of 50 (see Text S1 for more details). ${ }^{1}$

[10] DOC is included within PISCES-NP identically as for the original PISCES and is produced via the exudation of a fixed fraction of the organic carbon fixed during NPP, "sloppy feeding" by zooplankton grazers, and the disaggregation of particles. Bacteria are not treated as a functional group in PISCES, but there are several aspects to how remineralization is simulated. Variability in bacterial biomass is accounted for and parameterized implicitly using the results of a version of PISCES that did include bacteria explicitly (bacterial biomass is scaled to a function containing the abundance of microzooplankton and mesozooplankton and depth [see Aumont and Bopp, 2006]), limitation of bacterial remineralization by DOC and nutrients is included, and bacteria take up dissolved Fe. DOC is lost due to remineralization (as a function of temperature, bacterial limitation and bacterial biomass) and aggregation to $\mathrm{POC}$ as a function of the DOC concentration and particle load. Therefore, if extra DOC is produced (Exp PP-DOC $_{\text {D }}$ it has various potential fates. First, if bacteria are not nutrient limited, DOC will be remineralized back to DIC at the sea surface. Second, in regions where subduction is rapid or bacterial remineralization is limited by nutrients, DOC might be transported to the ocean interior, where the bulk of the remineralization will occur. Finally, DOC can aggregate/coagulate to form sinking particles that will also be remineralized in the ocean interior. Bacterial remineralization in the model is generally limited by nutrients in the oligotrophic gyres and by DOC elsewhere.

[11] Overall, the changes to PISCES-NP, relative to PISCES [Aumont and Bopp, 2006] are the addition of 14 tracers representing $\mathrm{N}$ and $\mathrm{P}$ in all pools and a reformulation of the $\mathrm{N}_{2}$ fixation parameterization. All other aspects are unchanged. In summary, PISCES-NP can be thought of as a "variable stoichiometry-Monod nutrient limitation" OGCBM and thus an intermediate step between "fixed stoichometry-Monod nutrient limitation" OGCBMs that are commonly used for global simulations and complex

${ }^{1}$ Auxiliary materials are available with the HTML. doi:10.1029/ 2010 GB003929. 
Table 2. A Summary of the Experimental Results ${ }^{\mathrm{a}}$

\begin{tabular}{|c|c|c|c|c|c|c|c|c|c|c|c|}
\hline Exp & Year & $\mathrm{CO}_{2}$ & $\mathrm{C} / \mathrm{N}$ & $\mathrm{C} / \mathrm{P}$ & $\mathrm{N} / \mathrm{P}$ & NPP & CEX & $\mathrm{FC}_{\text {ant }}$ & NF & $\mathrm{DN}$ & SOX \\
\hline \multirow{3}{*}{$\mathrm{CO}_{2}-\mathrm{CTL}$} & 1860 & 286.2 & 7.63 & 122 & 16 & 49.1 & 7.15 & - & 53.6 & 38.5 & 3.80 \\
\hline & 2000 & 368.9 & 7.63 & 122 & 16 & 49.1 & 7.15 & 2.34 & 51.7 & 39.3 & 3.80 \\
\hline & 2100 & 935.9 & 7.63 & 122 & 16 & 49.1 & 7.15 & 7.64 & 49.9 & 40.2 & 3.80 \\
\hline \multirow[t]{2}{*}{$\operatorname{Exp}_{P P}$} & 2000 & 368.9 & 2.9 & 3.3 & 0 & 3.1 & 2.9 & 3.3 & -0.99 & 8.5 & 4.6 \\
\hline & 2100 & 935.9 & 22.9 & 22.9 & 0 & 24.0 & 22.1 & 8.7 & -11.3 & 56.6 & 36.2 \\
\hline \multirow[t]{2}{*}{$\operatorname{Exp}_{\text {PP-DOC }}$} & 2000 & 368.9 & 0 & 0 & 0 & 2.7 & 0.6 & 1.3 & -0.30 & 5.3 & 1.76 \\
\hline & 2100 & 935.9 & 0 & 0 & 0 & 20.8 & 3.9 & 2.8 & -8.18 & 7.0 & 10.9 \\
\hline \multirow[t]{2}{*}{ Exp $_{\text {PP-PSiFe }}$} & 2000 & 368.9 & 2.9 & 0 & -3.1 & 1.1 & 1.0 & -0.3 & -15.8 & 4.8 & 3.1 \\
\hline & 2100 & 935.9 & 22.9 & 0 & -18.8 & 18.3 & 5.6 & 1.7 & -89.5 & 20.5 & 15.5 \\
\hline \multirow[t]{2}{*}{$\operatorname{Exp}_{P P-N}$} & 2000 & 368.9 & 2.9 & 0 & -3.1 & 1.4 & 0.1 & -0.1 & -16.8 & 3.5 & 0.1 \\
\hline & 2100 & 935.9 & 22.9 & 0 & -18.8 & 20.2 & -0.7 & -1.2 & -86.9 & -9.3 & -6.9 \\
\hline
\end{tabular}

${ }^{\mathrm{a}}$ We present the $\mathrm{pCO}_{2 \mathrm{~atm}}$ concentration (ppm) for years 1860, 2000 and 2100, results for the control simulation and then the percentage change in organic matter elemental ratios $(\mathrm{C} / \mathrm{N}, \mathrm{C} / \mathrm{P}$, and $\mathrm{N} / \mathrm{P})$, net primary productivity (NPP, $\left.\mathrm{PgC} \mathrm{yr}^{-1}\right)$, carbon export $\left(\mathrm{CEX}, \mathrm{PgC}\right.$ yr ${ }^{-1}$ at $\left.100 \mathrm{~m}\right)$, the uptake of anthropogenic $\mathrm{CO}_{2}\left(\mathrm{FC}_{\mathrm{ant}}, \mathrm{PgC} \mathrm{yr}^{-1}\right), \mathrm{N}_{2}$ fixation $\left(\mathrm{NF}, \mathrm{TgN} \mathrm{yr}{ }^{-1}\right)$, denitrification $\left(\mathrm{DN}, \mathrm{TgN}_{\mathrm{yr}}^{-1}\right)$ and the volume of suboxic waters $\left(\mathrm{SOX}, \times 10^{15} \mathrm{~m}^{3}\right.$, defined as $\left.\mathrm{O}_{2}<5 \times 10^{-6} \mathrm{~mol} \mathrm{~L}{ }^{-1}\right)$ for our model experiments in 2000 and 2100 . Values in bold and italics highlight increases and decreases, respectively. See Table 1 and Figure 1 for an explanation of the different model experiments.

"variable stoichiometry-quota nutrient limitation" models that are only used in one dimensional or regional frameworks [e.g., Litchman et al., 2006].

\subsection{Experimental Design}

[12] Similar to Oschlies et al. [2008], the experimental results of Riebesell et al. [2007] were used to prescribe an increase in the $\mathrm{C} / \mathrm{N}$ ratio as a function of $\mathrm{CO}_{2 \mathrm{~atm}}$. This nondimensional multiplicative factor is called the " $\mathrm{CO}_{2}$ sensitivity," and is shown in the bottom right panel of Figure 1. In $\operatorname{Exp}_{\mathrm{PP}}$, the $\mathrm{C}$ fixation rate is multiplied by this " $\mathrm{CO}_{2}$ sensitivity" factor. In Exp $\mathrm{DOC}_{\text {, }}$, the $\mathrm{C}$ fixation rate is also multiplied by this factor, but the "extra" $\mathrm{C}$ is immediately lost as DOC. In Exp PP-PSiFe $_{\text {the }} \mathrm{C}$ fixation rate and the uptake rates of $\mathrm{PO}_{4}, \mathrm{Fe}$ and $\mathrm{Si}$ are multiplied by the " $\mathrm{CO}_{2}$

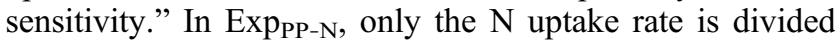
by the $\mathrm{CO}_{2}$ sensitivity. For example, the prescribed $\mathrm{CO}_{2}$ sensitivity is 1.1 and 1.2 at 2 and 3 times present-day $\mathrm{CO}_{2 \mathrm{~atm}}$, respectively. The model scenarios are summarized schematically in Figure 1. In order to isolate the impact of $\mathrm{OA}$, we chose to keep a constant ocean circulation during our experiments. Between 1860 and 2100 we forced our model with $\mathrm{CO}_{2 \mathrm{~atm}}$ concentrations from the recommended CMIP5 experimental protocol [Riahi et al., 2007], with both the experimental $\mathrm{CO}_{2 \mathrm{~atm}}$ concentrations and relative " $\mathrm{CO}_{2}$ sensitivity" for the biogeochemical processes considered are presented in the lower right-hand panel of Figure 1. For reference, our experiments are summarized in Table 1 and Figure 1. We conducted two control simulations, one with $\mathrm{CO}_{2 \mathrm{~atm}}$ fixed at 1860 levels (CTL) and another where $\mathrm{CO}_{2 \mathrm{~atm}}$ evolves $\left(\mathrm{CO}_{2}-\mathrm{CTL}\right)$, but there is no OA impact on primary productivity, DOC exudation and nutrient uptake rates (i.e., a "Redfield" run). Since our ocean circulation is unchanged for the duration of our experiments, we examine results from the final year of integration.

\subsection{Evaluation of PISCES-NP}

[13] Since PISCES-NP is by definition a "Redfield" model when $\mathrm{CO}_{2 \mathrm{~atm}}$ does not impact rate processes, the $\mathrm{CO}_{2}-\mathrm{CTL}$ simulation is essentially very similar to the standard version of PISCES [Aumont and Bopp, 2006].

[14] By 1994, the accumulation of anthropogenic carbon in the $\mathrm{CO}_{2}-\mathrm{CTL}$ simulation (relative to the CTL simulation fixed at $1860 \mathrm{CO}_{2 \mathrm{~atm}}$ levels) is $102.43 \mathrm{Pg}$, which compares well to the estimate of $119 \pm 19 \mathrm{Pg}$ by Sabine et al. [2004] that is referenced to the same year (1994) but also accounts for pre-1860 anthropogenic $\mathrm{CO}_{2}$ uptake. Mean annual air-sea anthropogenic $\mathrm{CO}_{2}$ fluxes $\left(\mathrm{FC}_{\mathrm{ant}}\right)$ are $2.248 \pm 0.121 \mathrm{Pg} \mathrm{C}$ for the 1990s, which also compare well to recent observationally based estimates [e.g., Takahashi et al., 2009; Le Quéré et al., 2009]. Modern NPP and CEX (at $100 \mathrm{~m}$ ) are 49.1 and $7.15 \mathrm{Pg} \mathrm{C} \mathrm{a}^{-1}$, respectively, which are of similar magnitude to estimates derived from satellite models or inverse modeling [e.g., Carr et al., 2006; Laws et al., 2000; Schlitzer, 2000]. In the $\mathrm{CO}_{2}-\mathrm{CTL}$ simulation there is approximately $50 \mathrm{Tg} \mathrm{N} \mathrm{a}$ of $\mathrm{N}_{2}$ fixation and $40 \mathrm{Tg} \mathrm{N} \mathrm{a}{ }^{-1}$ of denitrification between 1860 and 2100 .

[15] We compared modeled monthly surface $\mathrm{NO}_{3}, \mathrm{PO}_{4}$ and $\mathrm{O}_{2}$ from the $\mathrm{CO}_{2}$-CTL simulation to monthly values from the World Ocean Atlas 2005 climatology [Garcia et al., 2006a, 2006b]. For $\mathrm{NO}_{3}$, the regression coefficient (R) was 0.91 , with a slope of 0.87 and the mean observed and modeled values were $6.842 \pm 9.390$ and $7.699 \pm 9.313 \mu \mathrm{mol} \mathrm{L}{ }^{-1}$, respectively. For $\mathrm{PO}_{4}, \mathrm{R}$ was 0.93 , with a slope of 0.97 and the mean observed and modeled values were $0.675 \pm$ 0.620 and $0.523 \pm 0.672 \mu \mathrm{mol} \mathrm{L}{ }^{-1}$, respectively. For $\mathrm{O}_{2}, \mathrm{R}$ was 0.98 , with a slope of 1.00 and the mean observed and modeled values were $277.53 \pm 65.749$ and $278.98 \pm$ $65.014 \mu \mathrm{mol} \mathrm{L}^{-1}$, respectively. Surface dissolved Fe (dFe) also compares well to the observations collected in the database of Moore and Braucher [2008], where R was 0.62, the slope was 0.745 and the mean observed and modeled $\mathrm{dFe}$ were $0.319 \pm 3.603$ and $0.277 \pm 4.485 \mathrm{nmol} \mathrm{L}^{-1}$, respectively, between 0 and $100 \mathrm{~m}$.

\section{Results and Discussion}

\subsection{Carbon Cycling}

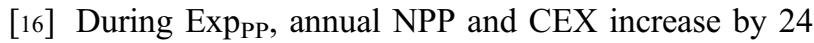
and $22 \%$ in 2100 , respectively, when OA increases the rate of primary production and $\mathrm{C} / \mathrm{N}$ ratios $\left(\mathrm{Exp}_{\mathrm{PP}}\right.$, Table 2$)$, which results in an $8.7 \%$ increase in annual $\mathrm{FC}_{\text {ant }}$, or a $38 \mathrm{Pg} \mathrm{C}$ increase in cumulative $\mathrm{FC}_{\mathrm{ant}}$ uptake over the period 1860 to 2100. The cumulative $\mathrm{FC}_{\mathrm{ant}}$ increase is similar to the additional $34 \mathrm{Pg}$ found by Oschlies et al. [2008], which is not surprising since the assumptions of $\operatorname{Exp}_{\mathrm{PP}}$ most closely 


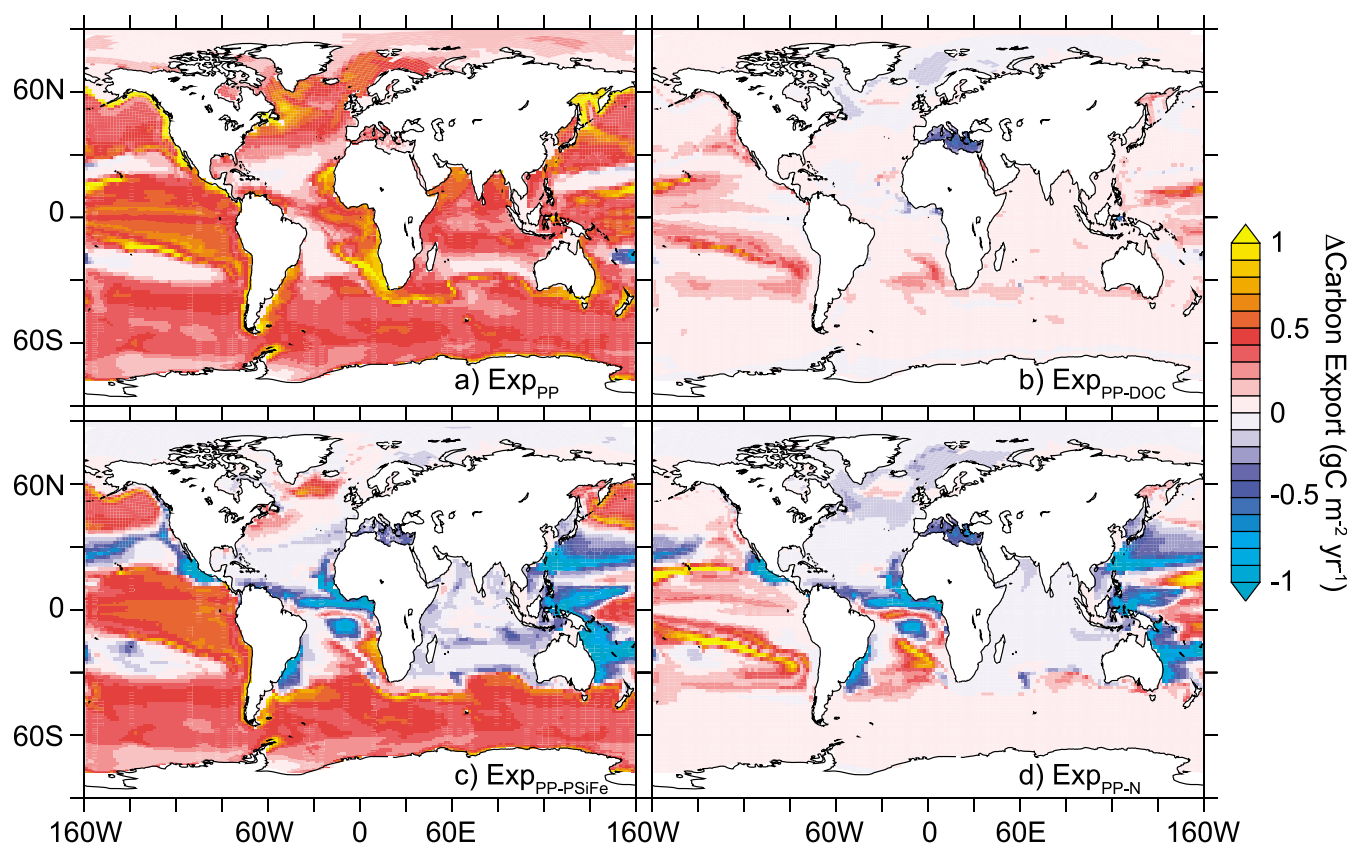

Figure 2. The absolute change in CEX (at $100 \mathrm{~m}, \mathrm{gC} \mathrm{m}^{-2} \mathrm{yr}^{-1}$ ) in 2100 for (a) $\operatorname{Exp}_{\mathrm{PP}}$, (b) Exp $\operatorname{Exp}_{\mathrm{P}-\mathrm{DOC}}$, (c) $\operatorname{Exp}_{\mathrm{PP}-\mathrm{PSiFe}}$, and (d) $\operatorname{Exp}_{\mathrm{PP}-\mathrm{N}}$ (see Figure 1 and Table 1 for details of the experiments).

match those applied by their model. CEX increases by $22 \%$ (Table 2) or by over $1 \mathrm{gC} \mathrm{m}^{-2} \mathrm{yr}^{-1}$ in some regions, with the smallest absolute changes in the oligotrophic gyres (Figure 2). Cumulative CEX increases from 1716.5 to $1796.0 \mathrm{Pg} \mathrm{C}$, an increase of $69.5 \mathrm{Pg} \mathrm{C}$, which is slightly less than the $100 \mathrm{Pg} \mathrm{C}$ found in simpler OGCBMs [Oschlies et al., 2008]. Greater NPP during $\operatorname{Exp}_{\mathrm{PP}}$ due to $\mathrm{CO}_{2}$ fertilization increases the concentration of phytoplankton carbon (as DOC losses were not enhanced concomitantly in this experiment), which PISCES-NP assumes results in larger cells that are consequently more $\mathrm{Fe}$ limited due to their reduced affinity for $\mathrm{Fe}$ (see Methods). Assuming slightly more $\mathrm{Fe}$ limited larger cells implicitly assumes that the greater NPP due to OA did not lead to more cell division. The greater $\mathrm{Fe}$ limitation that results causes increased surface water $\mathrm{NO}_{3}$ and, to a lesser degree, $\mathrm{PO}_{4}$. This effect only acts to reduce CEX in the extreme southwest Pacific Ocean (Figure 2a).

[17] The impact of $\mathrm{OA}$ on CEX and $\mathrm{FC}_{\text {ant }}$ is sensitive to modifying assumptions regarding the fate of fixed $\mathrm{C}$. If we assume all additional carbon fixed is lost as DOC (Exp PP-DOC $_{\text {, }}$, then while the change in annual NPP is similar to $\operatorname{Exp}_{\mathrm{PP}}(20.8 \%$, Table 2), the increases in annual $\mathrm{CEX}$ and $\mathrm{FC}_{\mathrm{ant}}$ are reduced (increases of 3.9 and $2.8 \%$, respectively, for $\operatorname{Exp}_{\mathrm{PP}-\mathrm{DOC}}$, Table 2). Although the additional DOC is exported to deeper waters by aggregation/coagulation, the increase in CEX would be over fivefold greater if the additional fixed $\mathrm{C}$ were exported as particulate organic carbon $\left(\mathrm{POC}, \mathrm{Exp}_{\mathrm{PP}}\right)$. The greatest increases in CEX due to DOC aggregation/coagulation are found away from high-productivity regions (i.e., in and around the oligotrophic gyres) wherein bacterial DOC remineralization rates are retarded due to nutrient limitation (Figure 2). This results in only a $13.2 \mathrm{Pg} \mathrm{C}$ increase in cumulative CEX by 2100, which is 5 times less than found during $\operatorname{Exp}_{\mathrm{PP}}$. The sensitivity of $\mathrm{FC}_{\mathrm{ant}}$ to increased
DOC production is slightly less and $\mathrm{FC}_{\mathrm{ant}}$ increases during Exp PP-DOC $_{\text {by approximately one quarter of what was }}$ found for Exp $p_{P P}$, with cumulative $\mathrm{CO}_{2}$ uptake $14 \mathrm{Pg} \mathrm{C}$ greater by 2100 (i.e., less than one third of $\operatorname{Exp}_{P P}$ ). Increased surface production of DOC promotes a more recycling food web (the ratio of NPP to CEX is increased by $>15 \%$ ) as its remineralization produces regenerated nutrients and shifts the phytoplankton community to nanophytoplankton dominance. Indeed, remineralization of DOC at the surface increases by $>50 \%$ by 2100 , which produces nutrients, but also DIC that weakens air-sea $\mathrm{CO}_{2}$ gradients and reduces the change in $\mathrm{FC}_{\mathrm{ant}}$. $\mathrm{DOC}$ is also removed from surface waters by subduction and by 2100 , there remains an additional $3.5 \mathrm{Tg}$ of DOC in the ocean that is not yet remineralized to DIC. This could be underestimated as our model only considers semilabile DOC and thus the potential production of more refractory DOC forms is not accounted for.

[18] If greater uptake of $\mathrm{PO}_{4}, \mathrm{Fe}$ and $\mathrm{Si}$ occurs alongside increased $\mathrm{CO}_{2}$ fixation (Exp $\mathrm{PP}_{\mathrm{PSiFe}}$ ) then we find large changes in the response of the $\mathrm{C}$ cycle, relative to the simulation where nutrient uptake was not impacted by OA (Table 2). First, the change in NPP is slightly less that during $\operatorname{Exp}_{\mathrm{PP}}$ (increasing by $18.3 \%$ ), due to greater uptake of $\mathrm{P}, \mathrm{Si}$ and $\mathrm{Fe}$ that increases limitation by these nutrients. CEX increases by $5.6 \%$ (thus between Exp PP-DOC $_{\text {and }}$ Exp $_{\mathrm{PP}}$ ), while the increase in $\mathrm{FC}_{\text {ant }}$ is $1.7 \%$, i.e., less than Exp PP-DOC. Cumulative $\mathrm{CO}_{2}$ uptake is $9 \mathrm{Pg} \mathrm{C}$ greater or over four times less than when increased NPP does not impact uptake of other nutrients $\left(\operatorname{Exp}_{\mathrm{PP}}\right)$. This is because during Exp $_{\text {PP-PSiFe }}$ CEX declines over large regions of the ocean (Figure 2, unlike $\operatorname{Exp}_{\mathrm{PP}}$ and $\operatorname{Exp}_{\mathrm{PP}-\mathrm{DOC}}$ ) as greater nutrient uptake causes increased limitation by $\mathrm{P}, \mathrm{Si}$, and $\mathrm{Fe}$. Therefore CEX can be reduced in some regions (in contrast to $\operatorname{Exp}_{\mathrm{PP}}$ and $\operatorname{Exp}_{\mathrm{PP}-\mathrm{DOC}}$ ) due to greater uptake of nutrients in adjacent waters (e.g., in the tropical Atlantic Ocean, Figure 2). Similar "downstream" effects are also found from 


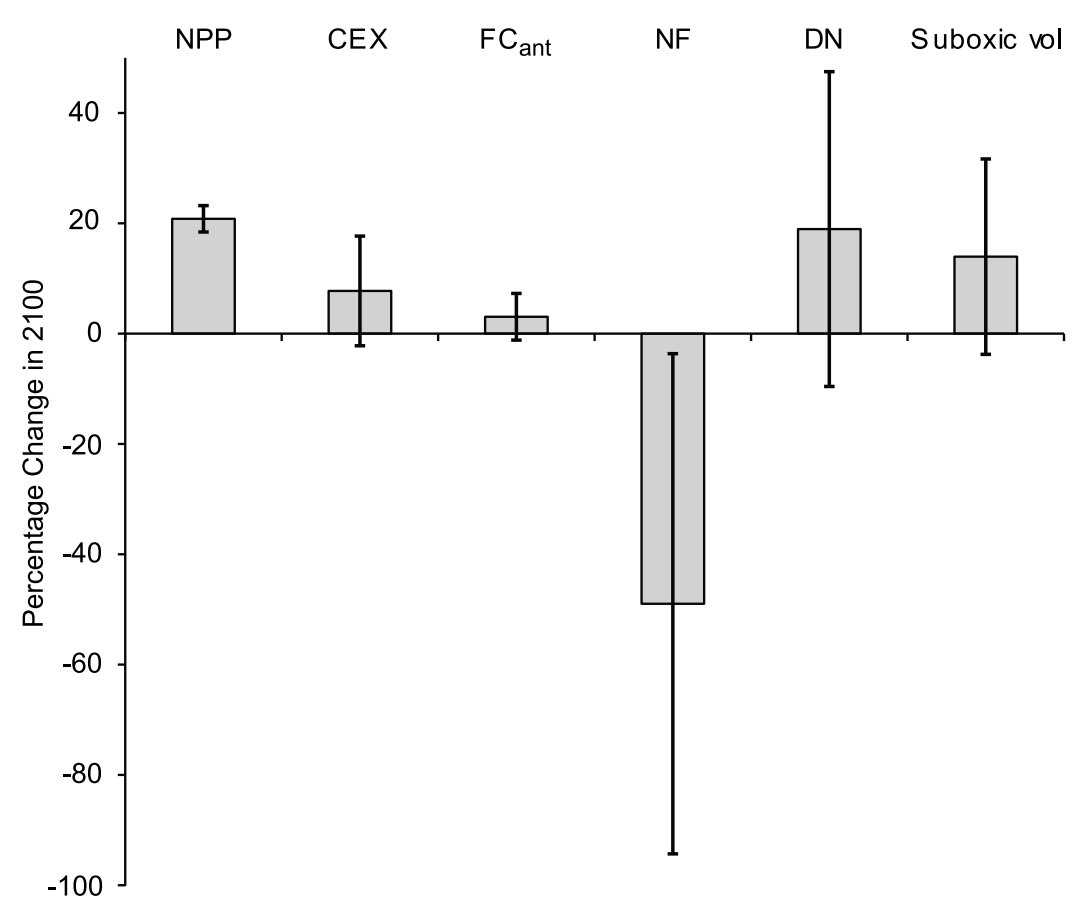

Figure 3. The mean percentage change in 2100 in NPP, CEX, $\mathrm{FC}_{\mathrm{ant}}, \mathrm{N}_{2}$ fixation (NF), denitrification (DN), and the volume of suboxic waters (suboxic volume) across all four experiments (see Figure 1 and Table 1 for details), with error bars representing one standard deviation.

east to west in the Pacific Ocean (Figure 2). Over our study period, this results in an increase of $22.4 \mathrm{Pg} \mathrm{C}$ in cumulative $\mathrm{CEX}$, relative to $\mathrm{CO}_{2}-\mathrm{CTL}$. As such, assumptions regarding the response of phytoplankton uptake of $\mathrm{P}, \mathrm{Si}$ and $\mathrm{Fe}$ to $\mathrm{OA}$ can impact the net change in $\mathrm{CEX}, \mathrm{FC}_{\mathrm{ant}}$, and nutrient limitation, as well as their spatial distribution.

[19] When OA impacts $N$ uptake $\left(\operatorname{Exp}_{\mathrm{PP}-\mathrm{N}}\right)$, NPP and CEX can only increase by indirect means. For example, less uptake of $\mathrm{N}$ per unit $\mathrm{C}$ results in more dissolved $\mathrm{N}$ remaining in surface waters, which can increase NPP in N limited waters (by 20\% globally, Table 2). However, greater NPP in N-limited waters results in increased uptake of other nutrients, which can then limit NPP and thus CEX in "downstream" areas. By 2100 this actually results in slightly less global CEX than the $\mathrm{CO}_{2}$-CTL experiment (by $-0.6 \%$, Table 2 and Figure 2) and cumulative CEX declines slightly, relative to $\mathrm{CO}_{2}-\mathrm{CTL}(-2.2 \mathrm{Pg} \mathrm{C})$. This is because more NPP is carried out by nanophytoplankton in 2100, which con-

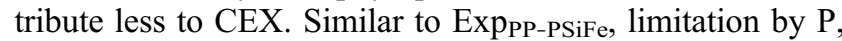
$\mathrm{Fe}$ and (for diatoms) Si increase greatly during this scenario due to greater uptake in $\mathrm{N}$-limited regions. Accordingly, $\mathrm{FC}_{\mathrm{ant}}$ is also reduced (by $1.2 \%$, Table 2) by 2100 , with $4 \mathrm{Pg} \mathrm{C}$ less cumulative $\mathrm{CO}_{2}$ uptake, relative to the $\mathrm{CO}_{2}-\mathrm{CTL}$.

[20] Overall, we can use the range of results from our sensitivity experiments to provide an assessment as to the uncertainties associated with model predicted biogeochemistry in 2100 (Figure 3). NPP changes little between the experiments and is more sensitive to the assumed impact of $\mathrm{CO}_{2}$ on a given process and NPP increases by $27 \pm 2 \%$ in 2100. CEX and $\mathrm{FC}_{\mathrm{ant}}$ changes are much more sensitive to our assumptions and overall we find that $\mathrm{CEX}$ and $\mathrm{FC}_{\mathrm{ant}}$ increase by $7.7 \pm 9.9 \%$ and $3.1 \pm 4.2 \%$, respectively, by
2100. This suggests that understanding the impact of OA on the ocean carbon cycle is sensitive to uncertainties related to the predicted impact of OA (unsurprisingly) for NPP. However, assumptions related to the fate of fixed $\mathrm{C}$ (POC or DOC) and the associated impact of lower $\mathrm{pH}$ on the uptake of other nutrients $(\mathrm{P}, \mathrm{Si}$, and $\mathrm{Fe})$ is important for understanding future $\mathrm{CEX}$ and $\mathrm{FC}_{\mathrm{ant}}$. It is noteworthy that the mean and range of changes we find here are as large as the predicted changes in NPP and CEX due to climate change alone from fixed stoichiometry models [Steinacher et al., 2010; Bopp et al., 2001, 2005].

\subsection{Nitrogen Cycling}

[21] During all experiments the change in denitrification is positively related to the change in CEX that results from $\mathrm{OA}$ (Figure 4). This is because increased CEX results in increased utilization of $\mathrm{O}_{2}$ in the subsurface for POC remineralization (see section 3.3), which then promotes more denitrification (as dissolved $\mathrm{O}_{2}$ is drawn down below a given threshold for denitrification). As such, where CEX increases greatly (e.g., Exp $\mathrm{PP}_{\mathrm{PP}}$ ), denitrification increases by up to $57 \%$, while if additional fixed carbon is lost as DOC (Exp PP-DOC $_{\text {or }}$ or uptake of other nutrients also increases (Exp $\mathrm{PP}-\mathrm{PSiFe})$, then the increase in denitrification is only between 7 to $20 \%$, respectively (Table 2). Since CEX declines slightly in Exp PP-N $_{\text {, denitrification also weakens }}$ slightly.

[22] We find the response of $\mathrm{N}_{2}$ fixation to be more complex and decoupled from changes in denitrification. For example, during Exp $\operatorname{EPP}_{\mathrm{PP}}$ and Exp $\mathrm{PP}_{\mathrm{PPOC}}, \mathrm{N}_{2}$ fixation declined moderately (by between 11 and $8 \%$, respectively, Table 2) because of greater limitation by Fe and P. However, when the N/P ratio of nutrient uptake was also assumed to change 
a)

b)
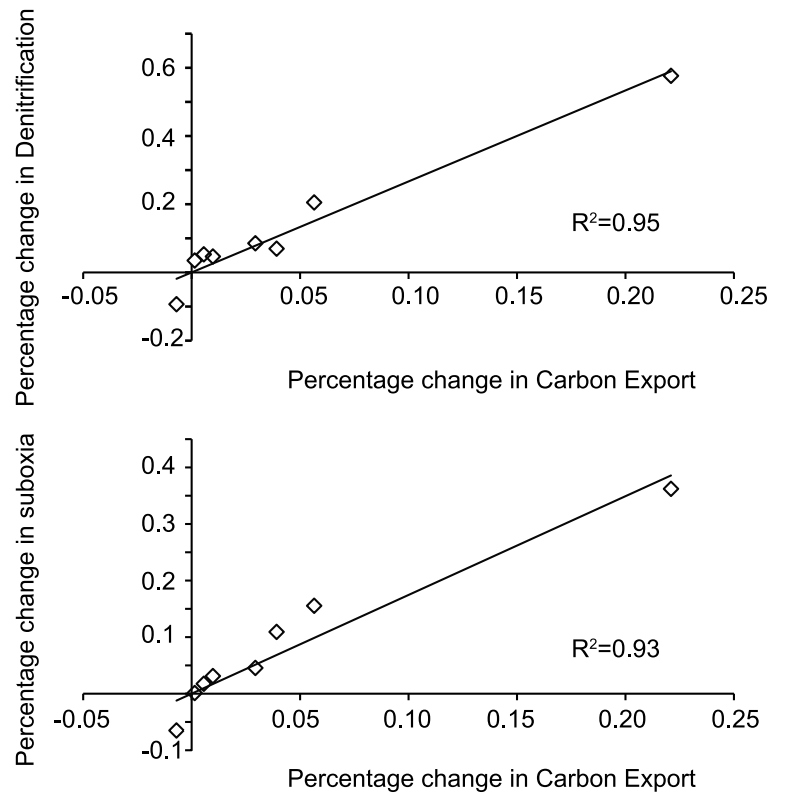

Figure 4. The relationship between the percentage change in CEX and (a) denitrification and (b) ocean suboxia (using results from the years 2000 and 2100).

$\left(\operatorname{Exp}_{\mathrm{PP}-\mathrm{PSiFe}}, \operatorname{Exp}_{\mathrm{PP}-\mathrm{N}}\right)$ we find dramatic reductions in $\mathrm{N}_{2}$ fixation (by over $80 \%$ ), despite up to $20 \%$ increases in denitrification (Table 2). It is noteworthy that large reductions in $\mathrm{N}_{2}$ fixation occur during both Exp $\operatorname{PP}_{\mathrm{PPS}} \mathrm{PSe}$ and Exp $_{\text {PP-N }}$, highlighting the importance of the overall N/P ratio, rather than greater $\mathrm{P}$ uptake. Therefore, this suggests that changes to the N/P ratio can profoundly impact $\mathrm{N}_{2}$ fixation and greatly decouple the response of $\mathrm{N}_{2}$ fixation from that of denitrification. This can be illustrated by the changes in the volume of surface waters (upper $50 \mathrm{~m}$ ) with $\mathrm{xsP}>0$ (i.e., additional $\mathrm{P}$ available for $\mathrm{N}_{2}$ fixers, $\mathrm{xsP}=\mathrm{PO}_{4}-\mathrm{NO}_{3} / 16$ ). We find little change in the "xsP $>0$ " volume between both $\operatorname{Exp}_{\mathrm{PP}}$ and ExpPP-DOC and the CTL simulation that parallels the moderate changes predicted for $\mathrm{N}_{2}$ fixation in these simulations (Figure 5). However, when we also assume decreases in $\mathrm{N} / \mathrm{P}$ ratios $\left(\operatorname{Exp}_{\mathrm{PP}-\mathrm{PSiFe}}\right.$ and $\left.\operatorname{Exp}_{\mathrm{PP}-\mathrm{N}}\right)$, we find a large consumption of xsP (Figure 5) that impedes any significant $\mathrm{N}_{2}$ fixation globally and profoundly alters the $\mathrm{N}_{2}$ fixationdenitrification balance. In all cases, $\mathrm{N}_{2}$ fixation declines due to the indirect effect of $\mathrm{OA}$ on nutrient concentrations mediated by nondiazotrophes. For experiments that do not impact the uptake of nutrients $\left(\operatorname{Exp}_{\mathrm{PP}}\right.$ and $\left.\operatorname{Exp}_{\mathrm{PP}-\mathrm{DOC}}\right)$, the slight reduction in $\mathrm{N}_{2}$ fixation arises due to greater limitation by $\mathrm{Fe}$ and increased surface $\mathrm{NO}_{3}$ concentrations, with little change in xsP (Figure 5). When nutrient uptake does change (Exp EP-PSiFe $_{\text {and }}$ Exp $\mathrm{PP}_{\mathrm{PP}-\mathrm{N}}$ ), the large reduction in $\mathrm{N}_{2}$ fixation appears to be due to greater $\mathrm{P}$ and $\mathrm{Fe}$ limitation or greater surface water $\mathrm{NO}_{3}$ (illustrated by the large changes to xsP, Figure 5).

[23] We can use the range in predicted responses from our suite of experiments to draw some conclusions about general trends and evaluate uncertainties (Figure 3). Unlike the $\mathrm{C}$ cycle, the $\mathrm{N}$ cycle is highly sensitive to assumptions related to the $\mathrm{CO}_{2}$ sensitivity, the fate of fixed DIC and the impact of $\mathrm{OA}$ on the uptake of other nutrients. $\mathrm{N}_{2}$ fixation always decreases in our experiments due to indirect impacts of OA (via nutrients), with a mean change of $-49 \pm 45 \%$ in 2100. In contrast, denitrification generally increases in response to CEX changes, with a mean change of $19 \pm 29 \%$ in 2100 . Overall, this clearly demonstrates the importance of the $\mathrm{CO}_{2}$ sensitivity, the fate of fixed $\mathrm{C}$, and the uptake of other nutrients in understanding how the balance of the oceanic fixed $\mathrm{N}$ inventory will be impacted by OA. The large standard deviations associated with the mean change in both processes reflect the high sensitivity of the change in both $\mathrm{N}_{2}$ fixation and denitrification in response to $\mathrm{OA}$ to our assumptions.

\subsection{Ocean Suboxia}

[24] Defining "suboxia" as waters characterized by an $\mathrm{O}_{2}$ concentration of $<5 \mu \mathrm{mol} \mathrm{L}{ }^{-1}$ permits us to examine the impact of our assumptions on the predicted change in ocean suboxia due to OA. Oschlies et al. [2008] report an increase in volume of suboxic waters of $50 \%$ by 2100 , which is slightly greater than the increase of $36 \%$ that we find in $\operatorname{Exp}_{\mathrm{PP}}$ (the scenario that most closely matches the Oschlies et al. [2008] study). However, changes in suboxia are closely related to changes in CEX (Figure 4) and thus in simulations where CEX increased by less (e.g., $\operatorname{Exp}_{\mathrm{PP}-\mathrm{DOC}}$ and $\left.\operatorname{Exp}_{\mathrm{PP}-\mathrm{PSiFe}}\right)$ the increase in suboxia is reduced to 10 $15 \%$ (Table 2). In Exp $\operatorname{PP}_{\mathrm{PP}}$, the large global increases in CEX reduce subsurface $\mathrm{O}_{2}$ everywhere (by up to $-20 \mu \mathrm{mol} \mathrm{L} \mathrm{L}^{-1}$, Figure 6). When extra DOC is produced (Exp PP-DOC $_{\text {), it is }}$ simply the lesser increase in CEX that reduces the "additional" $\mathrm{O}_{2}$ consumption in the subsurface $\left(\mathrm{O}_{2}\right.$ still declines everywhere, but by only up to $-10 \mu \mathrm{mol} \mathrm{L}{ }^{-1}$, Figure 6). However, when N/P ratios and/or uptake of $\mathrm{Fe}$ and $\mathrm{Si}$ also change $\left(\operatorname{Exp}_{\mathrm{PP}-\mathrm{PSiFe}}\right.$ and $\left.\operatorname{Exp}_{\mathrm{PP}-\mathrm{N}}\right)$, the CEX declines in some places (Table 2 and Figure 2) cause greater subsurface $\mathrm{O}_{2}$ in some regions (by around $5-10 \mu \mathrm{mol} \mathrm{L}^{-1}$ in the tropical Atlantic, Indian Ocean and western tropical Pacific,

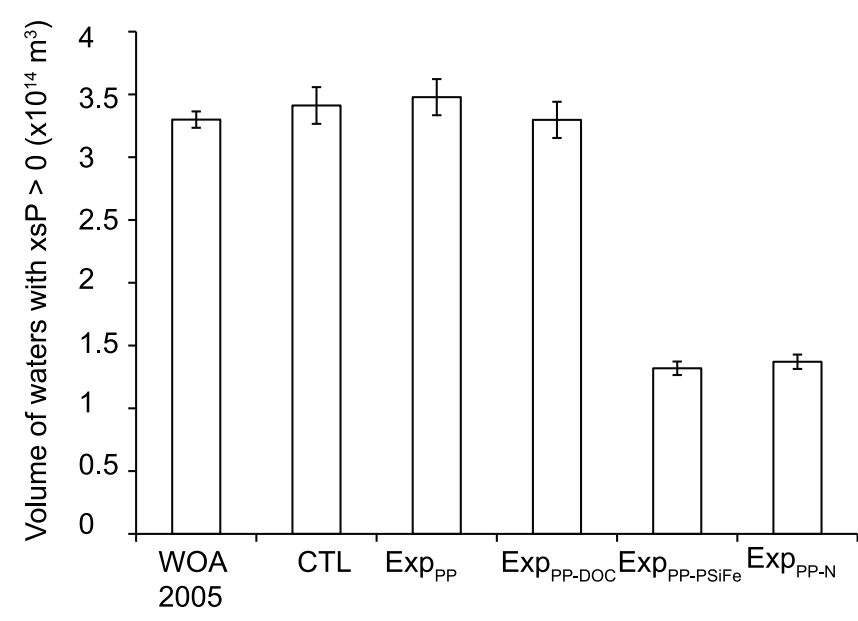

Figure 5. The integrated volume of the surface ocean $(0$ $50 \mathrm{~m})$ where $\mathrm{xsP}\left(\mathrm{PO}_{4}-\mathrm{NO}_{3} / 16\right)$ is greater than 0 , using monthly values from the World Ocean Atlas [Garcia et al., 2006b] and each model experiment in turn. The error bars represent one standard deviation of the monthly values. Results remain close to observed values for the CTL, $\operatorname{Exp}_{\mathrm{PP}}$, and $\operatorname{Exp}_{\mathrm{PP}-\mathrm{DOC}}$, but experiments with change to N/P ratios $\left(\operatorname{Exp}_{\mathrm{PP}-\mathrm{PS} i F e}\right.$ and $\left.\operatorname{Exp}_{\mathrm{PP}-\mathrm{N}}\right)$ result in large changes. 


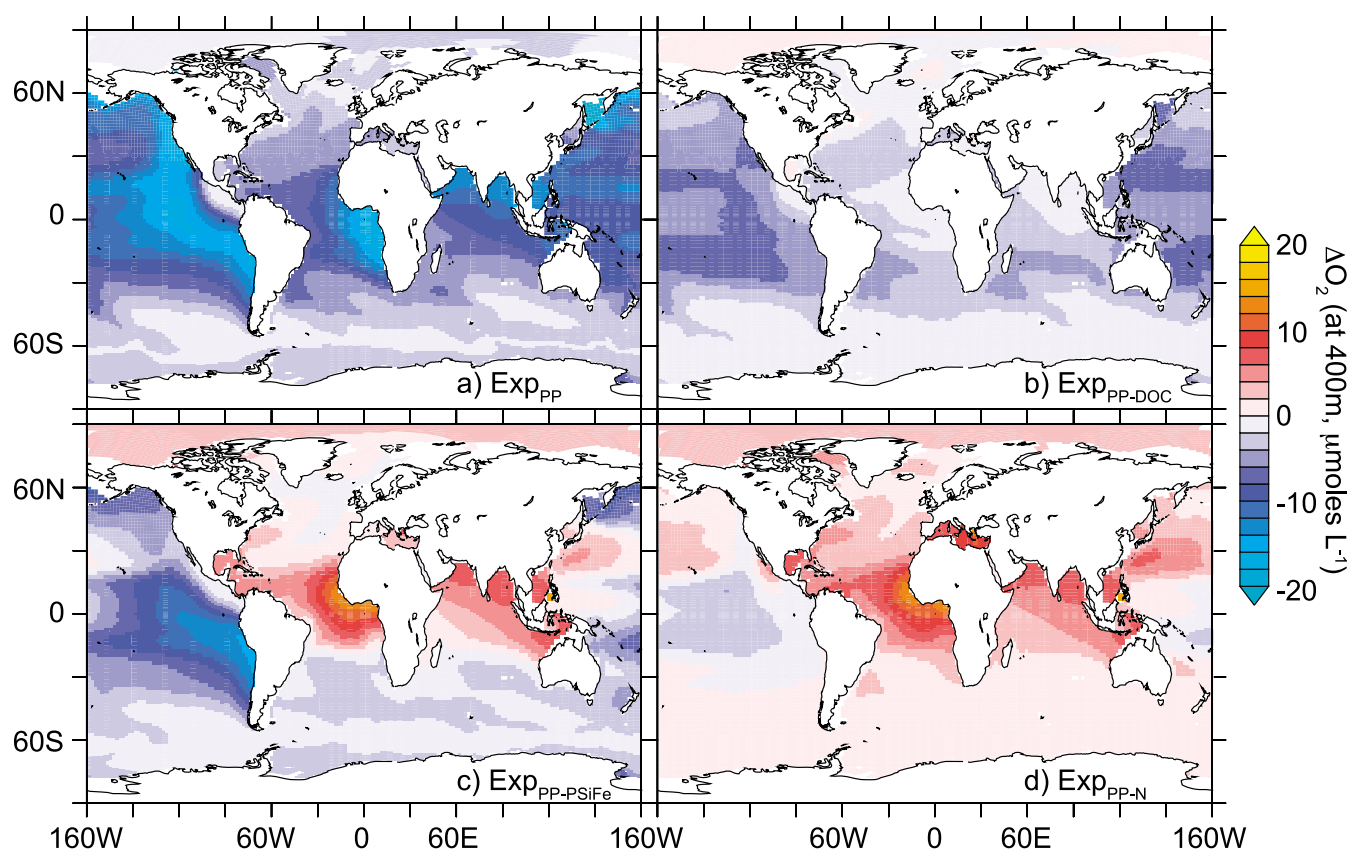

Figure 6. The absolute change in $\mathrm{O}_{2}\left(\mu \mathrm{mol} \mathrm{L}{ }^{-1}\right)$ at $400 \mathrm{~m}$ in 2100 for (a) Exp $\operatorname{EP}_{\mathrm{PP}}$, (b) Exp $\mathrm{EPP}_{\mathrm{PPOC}}$, (c) $\operatorname{Exp}_{\mathrm{PP}-\mathrm{PS} i F e}$, and (d) $\operatorname{Exp}_{\mathrm{PP}-\mathrm{N}}$ (see Figure 1 and Table 1 for details of the experiments).

Figure 6), with the suboxic volume increasing by $15 \%$ in Exp $_{\text {PP-PSiFe }}$ or declining by $7 \%$ in $\operatorname{Exp}_{\text {PP-N }}$ (Table 2). For all experiments, the changes in suboxia occur between 300 and $600 \mathrm{~m}$. Across our experiments, we find ocean suboxia increases by $14 \pm 17 \%$ in 2100 (Figure 3). Accordingly the prediction of the net change in ocean suboxia, as well as its spatial distribution is tightly linked to the assumed change in CEX (Figure 4) and is thus highly sensitive to assumptions related to the fate of fixed DIC, as well as modifications to nutrient uptake.

\section{Perspectives}

\subsection{Changing Stoichiometry in the Context of Climate Change Impacts}

[25] We can put the range of predicted changes in ocean biogeochemical processes due to OA into the context of the predicted changes due to climate change from fixed stoichiometry climate coupled OGCBMs. Concentrating on NPP and CEX (no results from coupled-climate OGCBMs are available for $\mathrm{N}_{2}$ fixation, denitrification and ocean suboxia), a recent study [Steinacher et al., 2010] using 3 coupled-climate OGCBMs found that NPP and CEX were reduced by $7-13$ and $6-20 \%$, respectively, by 2100 due to climate change. Similar results were obtained by Bopp et al. [2001, 2005] using biogeochemical and physical models of varying complexity, where CEX declined by $7-13 \%$ at $2 \times$ $\mathrm{CO}_{2}$ or $25 \%$ at $4 \times \mathrm{CO}_{2}$. More idealized experiments focusing on a slowdown in the Atlantic Meridional Overturning Circulation by Schmittner [2005] also suggest NPP and CEX declines of 10 to $20 \%$ after 1,200 years. Across our range of experiments, NPP and CEX change by +18 to $+24 \%$ (mean of $+21 \%$ ) and -0.6 to $+22 \%$ (mean of $+7.7 \%$ ) by 2100 due to OA modifying NPP and the stoichiometry of organic matter (Figures 1 and 2). This leads to two main points, the first is that the sign of the change due to OA is opposite to that which results from climate change and second, the magnitude of the change suggests that there is potential for OA effects to offset a large part of the climate change impact due to stoichiometric effects. Accordingly, including variability in $\mathrm{C} / \mathrm{N} / \mathrm{P}$ nutrient stoichiometry might be important in understanding the evolution of NPP and CEX over the coming century and fixed stoichiometry models may miss some of these feedbacks. Moreover, any changes in stoichiometry due to OA will also impact food quality available to grazers and thus the transfer efficiency to higher trophic levels will be affected [e.g., Dickman et al., 2008]. Addressing these questions necessitates "non-Redfield" OGCBMs that can be coupled to climate or marine resource models and in doing so, it will be important to examine the effect of OA driven variability in NPP, DOC production and nutrient stoichiometry alongside climate effects on ocean stratification and, in particular, vertical nutrient supply.

\subsection{Importance of Understanding the Fate of Fixed Carbon}

[26] Even if we assume that the "excess" NPP due to OA is lost from particulate organic matter pools due to enhanced DOC exudation we still find potential for enhanced CEX and $\mathrm{FC}_{\text {ant }}$. In our model this is due to two processes, DOC aggregation to POC and DOC subduction into the ocean interior. We find that aggregation of DOC can increase global $\mathrm{CEX}$ by around $4 \%$ and occurs in regions where DOC remineralization is limited by nutrients [Thingstad et al., 2008] (Figure 2). However, if TEP production also increases [Engel, 2002; Riebesell et al., 2007; Arrigo, 2007], then the aggregation flux of DOC might be greater than we find and our results should be seen as minimum estimates. Subduction of "unaggregated" DOC to the ocean interior 
means that this DOC will be remineralized back to $\mathrm{CO}_{2}$ away from the sea surface (depth-integrated DOC remineralization increases by $25 \%$ in 2100 during Exp PP-DOC $_{\text {. }}$. Once these waters return into contact with the atmosphere this $\mathrm{CO}_{2}$ will undergo ocean-atmosphere exchange and, depending on the $\mathrm{CO}_{2 \mathrm{~atm}}$ concentration at that time, might reduce the overall change in $\mathrm{FC}_{\mathrm{ant}}$. In addition, by $21003.5 \mathrm{Tg}$ of DOC remains in the ocean to be eventually remineralized. As such there is a "committed change" in (for example) $\mathrm{FC}_{\mathrm{ant}}$ and suboxia due to extra DOC production, of which only a certain fraction is actually realized by 2100 . The return to surface waters of additional DIC from the DOC that is already remineralized by 2100 in the ocean interior and that which will eventually be remineralized will impact air-sea $\mathrm{CO}_{2}$ fluxes decades to centuries after the initial perturbation. For example, assuming complete aerobic respiration, the stock of unremineralized DOC remaining in the ocean by 2100 in Exp PP-DOC will $_{2}$ reduce $\mathrm{O}_{2}$ levels by a further 3.3 Tmoles. This means that by 2100 our experiment has captured $77 \%$ of the committed change in the oceanic $\mathrm{O}_{2}$ inventory due to OA enhanced DOC production. As for $\mathrm{CEX}_{\text {and }} \mathrm{FC}_{\mathrm{ant}}$, it will also be important to understand these aspects in the context of climate impacts on ocean circulation. For example, a more stratified future ocean might increase the residence time of subsurface waters and thus delay the feedback of subsurface processes on airsea $\mathrm{CO}_{2}$ fluxes. On the other hand, less ventilation of subsurface waters due to climate change might exacerbate any OA-induced suboxia.

\subsection{Decoupling $\mathrm{N}_{2}$ Fixation and Denitrification in Response to Changing Stoichiometry}

[27] Throughout our experiments, the change in denitrification is strongly related to the change in CEX (Figure 4) and as such, is sensitive to assumptions made regarding the fate of fixed $\mathrm{C}$ and nutrient uptake in response to OA. However, the simulated change in $\mathrm{N}_{2}$ fixation was always opposite to that of denitrification, suggesting OA might imbalance the $\mathrm{N}$ cycle. In our study, OA only impacts directly upon non $\mathrm{N}_{2}$-fixing phytoplankton and therefore the $\mathrm{N}_{2}$ fixation response is indirect (mediated via changes in nutrient concentrations). If no change in $\mathrm{N} / \mathrm{P}$ ratios was assumed (Exp PP $_{\text {axd }}$ axp $\left.\operatorname{PP}_{\text {POC }}\right)$, then the changes in $\mathrm{N}_{2}$ fixation were slight ( -8 to $-11 \%$, Table 2$)$ and linked to the net NPP change. However, if N/P ratios were to decline in response to OA (Exp $\operatorname{EP}_{\mathrm{PPSiFe}}$ and $\left.\operatorname{Exp}_{\mathrm{PP}-\mathrm{N}}\right)$, then dramatic reductions in $\mathrm{N}_{2}$ fixation can occur (regardless of whether $\mathrm{N}$ or P uptake is impacted, Table 2). This is well illustrated by the change in the volume of waters with $\mathrm{xsP}>0$ during these experiments (Figure 5), with the resulting additional $\mathrm{NO}_{3}$ and reduced $\mathrm{PO}_{4}$ impeding $\mathrm{N}_{2}$ fixation over much of the ocean. As such, OA impacts $\mathrm{N}_{2}$ fixation due to indirect effects mediated by the impact of $\mathrm{OA}$ on nutrient stocks. The sensitivity of $\mathrm{N}_{2}$ fixation to $\mathrm{N} / \mathrm{P}$ ratios within an OCGBM in our study agrees with a recent box modeling study focusing on species-specific N/P ratios [Mills and Arrigo, 2010]. In addition to interspecific effects noted therein, we would also propose that intraspecific variability in N/P uptake in response to OA would also have profound consequences for $\mathrm{N}_{2}$ fixation over the coming century. On the other hand, recent studies have shown that $\mathrm{CO}_{2}$ can directly "fertilize" $\mathrm{N}_{2}$ fixation (a "direct" effect) [Hutchins et al., 2007; Barcelos e Ramos et al., 2007; Levitan et al.,
2007], which could compensate for indirect OA driven reductions due to $\mathrm{N} / \mathrm{P}$ ratio changes and thus needs to be assessed in multinutrient OGCBMs. To that end, it will be important to consider the role of nutrient limitation of $\mathrm{N}_{2}$ fixation, as well as N/P ratio impacts alongside direct $\mathrm{OA}$ effects [Fu et al., 2008; Hutchins et al., 2007, 2009]. For example, some studies have shown that OA increases $\mathrm{N}_{2}$ fixation despite P limitation [Hutchins et al., 2007]. Overall, understanding how OA acts in concert with climate change in governing the response of $\mathrm{N}_{2}$ fixation by 2100 will require a better understanding on how $\mathrm{CO}_{2}$ limits $\mathrm{N}_{2}$ fixation for parameterization in OGCBMs, the modulating role (if any) played by nutrient limitation ( $\mathrm{P}$ and/or $\mathrm{Fe}$ ) and also how the net N/P ratio of organic matter is likely to change in the future (the direct and indirect impacts, respectively, of $\mathrm{OA}$ on $\mathrm{N}_{2}$ fixation). It is also possible that OA might impact upon other $\mathrm{N}$ cycle processes, such as annamox or nitrification [e.g., Hutchins et al., 2009], which also needs to be assessed in models. Finally, if N/P ratios are related to how the environmental conditions of the mixed layer impact the growth strategy of the phytoplankton [Klausmeier et al., 2004], then climate change alone might impact future N/P ratios, and thus $\mathrm{N}_{2}$ fixation. Further experimental and modeling work is clearly needed to constrain these aspects.

\subsection{Overall Sensitivity and Evaluating Likely Scenarios}

[28] In general we find that our predictions for CEX, $\mathrm{N}_{2}$ fixation, denitrification, suboxia and nutrient limitation patterns have a high sensitivity to the assumptions explored during this study (Figure 3). On the other hand, NPP is more tightly controlled by the " $\mathrm{CO}_{2}$ sensitivity" applied, with only slight feedbacks due to the assumptions related to the fate of fixed $\mathrm{C}$ and nutrient uptake $( \pm 2 \%$, Figure 3$)$. This can be further illustrated by examining the relationship between NPP or CEX and $\mathrm{CO}_{2 \mathrm{~atm}}$. The prescribed $\mathrm{CO}_{2}$ sensitivity (Figure 1) can be used to predict the change in NPP or CEX as a function of $\mathrm{CO}_{2 \mathrm{~atm}}\left(17.5\right.$ and $2.55 \mathrm{Tg} \mathrm{C} \mathrm{ppm}{ }^{-1}$, for NPP and CEX, respectively, Table 3) and examining the actual relationship between NPP or CEX and $\mathrm{CO}_{2 \mathrm{~atm}}$ that arises over the course of our simulations can then illustrate the impact of our assumptions and nonlinearities in the ocean biogeochemical system (Table 3). For example, the slope of the NPP versus $\mathrm{CO}_{2 \mathrm{~atm}}$ across all our experiments (13.4$18.5 \mathrm{Tg} \mathrm{C} \mathrm{pmm}^{-1}$, with a mean of $\left.16 \pm 2 \mathrm{Tg} \mathrm{C} \mathrm{pmm}^{-1}\right)$ is virtually identical to that predicted by the prescribed $\mathrm{CO}_{2}$

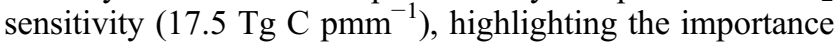
of the assumed $\mathrm{CO}_{2}$ sensitivity of $\mathrm{CO}_{2}$ fixation and a weak influence of assumptions related to the fate of fixed $\mathrm{C}$ and nutrient uptake in understanding the evolution of NPP. Evidently, feedbacks from modified nutrient cycling have only a weak impact on NPP, perhaps due to phytoplankton species shifts (with differing nutrient requirements) moderating the net effect. In contrast, the slope of the CEX versus $\mathrm{CO}_{2 \mathrm{~atm}}$ relationship shows much greater variability

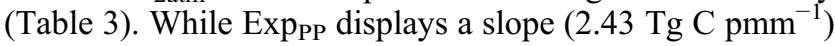
that is very similar to that predicted from the $\mathrm{CO}_{2}$ sensitivity alone $\left(2.55 \mathrm{Tg} \mathrm{C} \mathrm{pmm}^{-1}\right)$, the slope declines greatly to 0.4 , 0.6 , and $-0.09 \mathrm{Tg} \mathrm{C} \mathrm{pmm}^{-1}$ for $\operatorname{Exp}_{\mathrm{PP}-\mathrm{DOC}}$, Exp $\mathrm{EPP}_{\mathrm{PSiF}}$, and $\operatorname{Exp}_{\mathrm{PP}-\mathrm{N}}$, respectively, with a mean change of $0.84 \pm$ $1.10 \mathrm{Tg} \mathrm{C} \mathrm{pmm}^{-1}$ across all experiments. The large standard deviation $(\sim 130 \%$ of the mean) highlights the sensitivity 
Table 3. The Slope of the Relationship Between Both Annual NPP and $\mathrm{CEX}$ and $\mathrm{pCO}_{2 \mathrm{~atm}}\left(\mathrm{Tg} \mathrm{C} \mathrm{pmm}^{-1}\right)$ for All Our Experiments and That Predicted From the $\mathrm{CO}_{2}$ Sensitivity Alone $(0.002714 \mathrm{ppm}$ $\mathrm{CO}_{2 \mathrm{~atm}}^{-1}$ ) Over the Period 1860 to 2100 , With the Mean \pm 1 Standard Deviation $^{\text {a }}$

\begin{tabular}{llc}
\hline & \multicolumn{2}{c}{ Slope $\left(\mathrm{Tg} \mathrm{C} \mathrm{pmm}^{-1}\right)$} \\
\cline { 2 - 3 } & \multicolumn{1}{c}{ NPP } & CEX \\
\hline Predicted $^{\mathrm{b}}$ & 17.47 & 2.55 \\
Expp $_{\text {PP }}$ & 18.45 & 2.43 \\
ExpP-DOC $_{\text {Exp }}$ & 15.94 & 0.40 \\
Exp-PSPFe $_{\text {Mean }} \pm$ stdev & 13.44 & 0.63 \\
& 16.56 & -0.09 \\
& $16.10 \pm 2.07$ & $0.84 \pm 1.10$ \\
\hline
\end{tabular}

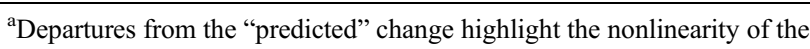
ocean biogeochemical system.

${ }^{\mathrm{b}}$ Predicted by applying the prescribed $\mathrm{CO}_{2}$ sensitivity (Figure 1) to 1860 values of NPP and CEX and using the enforced change in $\mathrm{pCO}_{2 \mathrm{~atm}}$ (Figure 1)

of the $\mathrm{CEX}$ versus $\mathrm{CO}_{2 \mathrm{~atm}}$ relationship to the assumptions related to the fate of fixed $\mathrm{C}$ and nutrient uptake examined in this study (Table 3). Moreover, that the actual change in CEX is markedly different to that predicted using the $\mathrm{CO}_{2}$ sensitivity alone illustrates the nonlinear behavior of the system, whereby changes in species composition due to modified nutrient cycling, for example, can drive large variability (relative to that predicted) in CEX, but not in NPP.

[29] Our different scenarios can be summarized by their impact on $\mathrm{C} / \mathrm{N}, \mathrm{C} / \mathrm{X}$ and $\mathrm{N} / \mathrm{X}$ ratios (where $\mathrm{X}=\mathrm{P}, \mathrm{Fe}$, or $\mathrm{Si}$ ), which can be compared to available data sets in order to evaluate which, if any, can be supported. The change in these ratios is tabulated in Table 1, and to recall, $\operatorname{Exp}_{\mathrm{PP}}$ had increased $\mathrm{C} / \mathrm{N}, \mathrm{C} / \mathrm{X}$ and unchanged N/X, Exp $\mathrm{EP-DOC}$ had no change in any organic matter ratios (excess $\mathrm{C}$ lost as DOC), and both Exp PP-PSiFe $_{\text {and }}$ Exp $_{\mathrm{PP}-\mathrm{N}}$ had increased $\mathrm{C} / \mathrm{N}$, reduced $\mathrm{N} / \mathrm{X}$ and unchanged $\mathrm{C} / \mathrm{X}$ ratios. In their review, Hutchins et al. [2009] compile available data on changes to $\mathrm{C} / \mathrm{N}$ and $\mathrm{N} / \mathrm{P}$ ratios in response to OA. Examining the results for cultured eukaryotic phytoplankton, in the 13 studies compiled by Hutchins et al. [2009, and references therein], the $\mathrm{C} / \mathrm{N}$ ratio increased in 5 , was unchanged in 6 and declined in 1. Concerning N/P ratios, in the 10 studies for which data were compiled, N/P ratios increased during 4 , declined in 1 and were unchanged in 5 [Hutchins et al., 2009, and references therein]. For natural assemblages, studies have shown increases, decreases and no change in $\mathrm{C} / \mathrm{N}$ and $\mathrm{N} / \mathrm{P}$, although accompanying shifts in species composition due to OA might complicate the interpretation [Hutchins et al., 2009, and references therein]. Unfortunately, much less information exists for postulated changes in $\mathrm{C} / \mathrm{Fe}$ and $\mathrm{C} / \mathrm{Si}$ ratios in response to $\mathrm{OA}$, which will also be difficult to directly attribute to $\mathrm{OA}$ since $\mathrm{C} / \mathrm{Fe}$ and $\mathrm{C} / \mathrm{Si}$ show a large degree of variability as a function of environmental variability (e.g., nutrient concentrations, light levels, species composition). Overall, it appears very difficult at this stage to assess which of our scenarios is most plausible. Nevertheless we can highlight the importance of constraining the " $\mathrm{CO}_{2}$ sensitivity" of rate processes (e.g., for NPP), the fate of fixed $\mathrm{C}$ (e.g., as DOC), and the ensuing N/P ratio as critical to evaluating the impact of OA on ocean biogeochemistry. Our model attempts to address the potential effects of variable stoichiometry by imposing changes in the uptake of $\mathrm{C}$ and other nutrients. Future work that deals with "non-Redfield" nutrient uptake in a more mechanistic sense is clearly necessary, but will require a careful consideration of how the processes driving the variability in $\mathrm{C}$ and nutrient uptake by phytoplankton are represented.

\section{Conclusions}

[30] Our experiments demonstrate that assumptions related to the fate of fixed carbon and the associated impacts on the uptake of multiple nutrients result in large uncertainties regarding the response of ocean biogeochemistry to OA. In particular, modifications to the uptake of $\mathrm{N}, \mathrm{P}, \mathrm{Si}$ and $\mathrm{Fe}$ alongside the possible changes in primary production can impact the magnitude of the change in important biogeochemical processes such as $\mathrm{CEX}, \mathrm{FC}_{\mathrm{ant}}, \mathrm{N}_{2}$ fixation, denitrification and ocean suboxia. The change in NPP is more sensitive to the assumed " $\mathrm{CO}_{2}$ sensitivity" of $\mathrm{CO}_{2}$ fixation. Further careful laboratory and field experiments are urgently needed to better constrain the likely response of $\mathrm{C}$ and nutrient cycling by diverse phytoplankton taxa in response to $\mathrm{OA}$ and complex OGCBMs that resolve stoichiometric variability are needed to assess their impacts. That said, our suite of experiments appear to give an idea as to the likely sign of the anticipate change. As such, we suggest that NPP, CEX, $\mathrm{FC}_{\mathrm{ant}}$, denitrification and ocean suboxia will all increase, while $\mathrm{N}_{2}$ fixation will decrease due to $\mathrm{OA}$ (Figure 3). Overall, the sensitivity we find to changes in stoichiometry and physiology are as large as the changes in NPP and CEX predicted from fixed stoichiometry coupled OGCBMs in response to climate change [Steinacher et al., 2010], which suggests the impact of OA on stoichiometry might be as large as the "direct" climate change impact. Nevertheless, we reiterate that the likely magnitude of these changes remains poorly constrained due to uncertainties in the response of, in particular, phytoplankton nutrient uptake to $\mathrm{OA}$ and the " $\mathrm{CO}_{2}$ sensitivity" of rate processes (Figure 3). A coupled experimental - modeling approach will help to better illuminate these aspects in the future.

[31] Acknowledgments. This work is a contribution to the "European Project of Ocean Acidification" (EPOCA) which received funding from the European Community's Seventh Framework Programme (FP7/ 2007-2013) under grant agreement 211384. We thank Christian Ethé for help setting up PISCES-NP and Dave Hutchins for comments, ideas, and discussion of this work. The comments of two anonymous reviewers improved this manuscript.

\section{References}

Anderson, T. R., and A. Mitra (2010), Dysfunctionality in ecosystem models: An underrated pitfall?, Prog. Oceanogr., 84(1-2), 66-68, doi:10.1016/j.pocean.2009.09.007.

Arrigo, K. R. (2007), Carbon cycle: Marine manipulations, Nature, 450, 491-492, doi:10.1038/450491a.

Arrigo, K. R., D. H. Robinson, D. L. Worthen, R. B. Dunbar, G. R. DiTullio, M. VanWoert, and M. P. Lizotte (1999), Phytoplankton community structure and the drawdown of nutrients and $\mathrm{CO}_{2}$ in the Southern Ocean, Science, 283, 365-367, doi:10.1126/science.283.5400.365.

Aumont, O., and L. Bopp (2006), Globalizing results from ocean in situ iron fertilization studies, Global Biogeochem. Cycles, 20, GB2017, doi:10.1029/2005GB002591.

Barcelos e Ramos, J., H. Biswas, K. G. Schulz, J. LaRoche, and U. Riebesell (2007), Effect of rising atmospheric carbon dioxide on the marine nitrogen 
fixer Trichodesmium, Global Biogeochem. Cycles, 21, GB2028, doi:10.1029/2006GB002898.

Bellerby, R. G. J., K. G. Schulz, U. Riebesell, C. Neill, G. Nondal, E. Heegaard, T. Johannessen, and K. R. Brown (2008), Marine ecosystem community carbon and nutrient uptake stoichiometry under varying ocean acidification during the PeECE III experiment, Biogeosciences, 5, 1517-1527, doi:10.5194/bg-5-1517-2008.

Blain, S., C. Guieu, H. Claustre, K. Leblanc, T. Moutin, B. Queguiner, J. Ras, and G. Sarthou (2004), Availability of iron and major macronutrients for phytoplankton in the northeast Atlantic Ocean, Limnol. Oceanogr., 49, 2095-2104, doi:10.4319/lo.2004.49.6.2095.

Bopp, L., P. Monfray, O. Aumont, J.-L. Dufresne, H. Treut, G. Madec L. Terray, and J. Orr (2001), Potential Impact of Climate Change on Marine Export Production, Global Biogeochem. Cycles, 15(1), 81-99, doi:10.1029/1999GB001256.

Bopp, L., O. Aumont, P. Cadule, S. Alvain, and M. Gehlen (2005), Response of diatoms distribution to global warming and potential implications: A global model study, Geophys. Res. Lett., 32, L19606, doi:10.1029/2005GL023653.

Breitbarth, E., R. J. Bellerby, C. C. Neill, M. V. Ardelan, M. Meyerhöfer, E. Zöllner, P. L. Croot, and U. Riebesell (2010), Ocean acidification affects iron speciation during a coastal seawater mesocosm experiment Biogeosciences, 7, 1065-1073, doi:10.5194/bg-7-1065-2010.

Caldeira, K., and M. E. Wickett (2003), Anthropogenic carbon and ocean $\mathrm{pH}$, Nature, 425, 365, doi:10.1038/425365a.

Carr, M.-E., et al. (2006), A comparison of global estimates of marine primary production from ocean color, Deep Sea Res., 53, 741-770, doi:10.1016/j.dsr2.2006.01.028

Denman, K. L., et al. (2007), Couplings between changes in the climate system and biogeochemistry, in Climate Change 2007: The Physical Science Basis. Contribution of Working Group I to the Fourth Assessment Report of the Intergovernmental Panel on Climate Change, edited by S. Solomon et al., pp. 499-587, Cambridge Univ. Press, Cambridge, U. K.

Dickman, E. M., J. M. Newell, M. J. Gonzalez, and M. J. Vanni (2008), Light, nutrients, and food-chain length constrain planktonic energy transfer efficiency across multiple trophic levels, Proc. Natl. Acad. Sci. U. S. A., 105, 18,408-18,412.

Engel, A. (2002), Direct relationship between $\mathrm{CO}_{2}$ uptake and transparent exopolymer particles in natural phytoplankton, J. Plankton Res., 24, 49-53, doi:10.1093/plankt/24.1.49.

Fabry, V. J. (2008), Ocean science: Marine calcifiers in a high- $\mathrm{CO}_{2}$ ocean, Science, 320, 1020-1022, doi:10.1126/science.1157130.

Feng, Y., et al. (2010), Interactive effects of iron, irradiance and $\mathrm{CO}_{2}$ on Ross Sea phytoplankton, Deep Sea Res., Part I, 57, 368-383, doi:10.1016/j.dsr.2009.10.013.

Finkel, Z. V., J. Beardall, K. J. Flynn, A. Quigg, T. A. V. Rees, and J. A. Raven (2010), Phytoplankton in a changing world: Cell size and elemental stoichiometry, J. Plankton Res., 32, 119-137, doi:10.1093/plankt/ fbp098.

Fu, F., M. E. Warner, Y. Zhang, Y. Feng, and D. A. Hutchins (2007), Effects of increased temperature and $\mathrm{CO}_{2}$ on photosynthesis, growth and elementa ratios of marine Synechococcus and Prochlorococcus (Cyanobacteria), J. Phycol., 43, 485-496, doi:10.1111/j.1529-8817.2007.00355.x.

Fu, F., M. R. Mulholland, N. Garcia, A. Beck, P. W. Bernhardt, M. E. Warner, S. A. Sanudo-Wilhelmy, and D. A. Hutchins (2008), Interactions between changing $\mathrm{pCO}_{2}, \mathrm{~N}_{2}$ fixation, and Fe limitation in the marine unicellular cyanobacterium Crocosphaera, Limnol. Oceanogr. 53, 2472-2484, doi:10.4319/10.2008.53.6.2472

Garcia, H. E., R. A. Locarnini, T. P. Boyer, and J. I. Antonov (2006a) World Ocean Atlas 2005, vol. 4, Nutrients (Phosphate, Nitrate, Silicate), edited by S. Levitus, NOAA Atlas NESDIS 64, 396 pp., U.S. Govt. Print. Off., Washington, D. C

Garcia, H. E., R. A. Locarnini, T. P. Boyer, and J. I. Antonov (2006b), World Ocean Atlas 2005, vol. 3, Dissolved Oxygen, Apparent Oxygen Utilization, and Oxygen Saturation, edited by S. Levitus, NOAA Atlas NESDIS 63, 342 pp., U.S. Govt. Print. Off., Washington, D. C.

Gordillo, F. J. L., C. Jimenez, F. L. Figueroa, and F. X. Niell (2003), Influence of elevated $\mathrm{CO}_{2}$ and nitrogen supply on the carbon assimilation performance and cell composition of the unicellular alga Dunaliella viridis, Physiol. Plant., 119, 513-518, doi:10.1046/j.1399-3054.2003.00192.x.

Hein, M., and K. Sand-Jensen (1997), $\mathrm{CO}_{2}$ increases oceanic primary production, Nature, 388(6642), 526-527, doi:10.1038/41457.

Hutchins, D. A., F. Fu, Y. Zhang, M. E. Warner, Y. Feng, K. Portune, P. W. Bernhardt, and M. R. Mulholland (2007), $\mathrm{CO}_{2}$ control of Trichodesmium $\mathrm{N}_{2}$ fixation, photosynthesis, growth rates, and elemental ratios: Implications for past, present, and future ocean biogeochemistry, Limnol. Oceanogr., 52, 1293-1304, doi:10.4319/lo.2007.52.4.1293.
Hutchins, D. A., M. R. Mulholland, and F. Fu (2009), Nutrient cycles and marine microbes in a $\mathrm{CO}_{2}$-enriched ocean, Oceanography, 22, 128-145.

Klausmeier, C. A., E. Litchman, T. Daufresne, and S. A. Levin (2004), Optimal nitrogen-to-phosphorus stoichiometry of phytoplankton, Nature, 429, 171-174, doi:10.1038/nature02454

Laws, E. A., P. G. Falkowski, W. O. Smith Jr., H. Ducklow, and J. J. McCarthy (2000), Temperature effects on export production in the open ocean, Global Biogeochem. Cycles, 14, 1231-1246, doi:10.1029/ 1999GB001229.

Le Quéré, C., et al. (2009), Trends in the sources and sinks of carbon dioxide, Nat. Geosci., 2, 831-836, doi:10.1038/ngeo689.

Levitan, O., G. Rosenberg, I. Setlik, E. Setlikova, J. Grigel, J. Klepetar, O. Prasil, and I. Berman-Frank (2007), Elevated $\mathrm{CO}_{2}$ enhances nitrogen fixation and growth in the marine cyanobacterium Trichodesmium, Global Change Biol., 13, 531-538, doi:10.1111/j.1365-2486.2006.01314.x.

Litchman, E., C. A. Klausmeier, J. R. Miller, O. M. Schofield, and P. G. Falkowski (2006), Multi-nutrient, multi-group model of present and future oceanic phytoplankton communities, Biogeosciences, 3, 585-606, doi:10.5194/bg-3-585-2006

Milligan, A. J., D. E. Varela, M. A. Brzezinski, and F. M. M. Morel (2004), Dynamics of silicon metabolism and silicon isotopic discrimination in marine diatom as a function of $\mathrm{pCO}_{2}$, Limnol. Oceanogr., 49, 322-329, doi:10.4319/lo.2004.49.2.0322.

Mills, M. M., and K. R. Arrigo (2010), Magnitude of oceanic nitrogen fixation influenced by the nutrient uptake ratio of phytoplankton, Nat. Geosci., 3, 412-416, doi:10.1038/ngeo856.

Moore, J. K., and O. Braucher (2008), Sedimentary and mineral dust sources of dissolved iron to the world ocean, Biogeosciences, 5, 631-656, doi:10.5194/bg-5-631-2008.

Moore, J. K., and S. C. Doney (2007), Iron availability limits the ocean nitrogen inventory stabilizing feedbacks between marine denitrification and nitrogen fixation, Global Biogeochem. Cycles, 21, GB2001, doi:10.1029/2006GB002762

Orr, J. C., et al. (2005), Anthropogenic ocean acidification over the twentyfirst century and its impact on calcifying organisms, Nature, 437, 681-686, doi:10.1038/nature04095.

Oschlies, A., K. G. Schulz, U. Riebesell, and A. Schmittner (2008), Simulated 21st century's increase in oceanic suboxia by $\mathrm{CO}_{2}$-enhanced biotic carbon export, Global Biogeochem. Cycles, GB4008, doi:10.1029/ 2007GB003147.

Raven, J. A., and A. M. Johnston (1991), Mechanisms of inorganic-carbon acquisition in marine phytoplankton and their implications for the use of other resources, Limnol. Oceanogr., 36(8), 1701-1714, doi:10.4319/ lo.1991.36.8.1701.

Redfield, A. C. (1934), On the proportions of organic derivations in sea water and their relation to the composition of plankton, in James Johnstone Memorial Volume, edited by R. J. Daniel, pp. 177-192, Univ. Press of Liverpool, Liverpool, U. K.

Riahi, K., A. Gruebler, and N. Nakicenovic (2007), Scenarios of long-term socio-economic and environmental development under climate stabilization, Technol. Forecast. Social Change, 74(7), 887-935.

Ridgwell, A., D. N. Schmidt, C. Turley, C. Brownlee, M. T. Maldonado, P. Tortell, and J. R. Young (2009), From laboratory manipulations to Earth system models: Scaling calcification impacts of ocean acidification, Biogeosciences, 6, 2611-2623, doi:10.5194/bg-6-2611-2009.

Riebesell, U., D. Wolf-Gladrow, and V. Smetacek (1993), Carbon dioxide limitation of marine phytoplankton growth rates, Nature, 361, 249-251, doi: $10.1038 / 361249 \mathrm{a} 0$

Riebesell, U., et al. (2007), Enhanced biological carbon consumption in a high $\mathrm{CO}_{2}$ ocean, Nature, 450, 545-549, doi:10.1038/nature06267.

Riebesell, U., A. Körtzinger, and A. Oschlies (2009), Sensitivities of marine carbon fluxes to ocean change, Proc. Natl. Acad. Sci. U. S. A., 106, 20,602-20,609, doi:10.1073/pnas.0813291106.

Sabine, C. L., et al. (2004), The oceanic sink for anthropogenic $\mathrm{CO}_{2}$, Science, 305, 367-371, doi:10.1126/science.1097403.

Schlitzer, R. (2000), Applying the adjoint method for global biogeochemical modeling, in Inverse Methods in Biogeochemical Cycles, edited by P. Kasibhatla et al., pp. 107-124, AGU, Washington, D. C.

Schmittner, A. (2005), Decline of the marine ecosystem caused by a reduction in the Atlantic overturning circulation, Nature, 434, 628-633, doi:10.1038/nature03476.

Schneider, B., A. Engel, and R. Schlitzer (2004), Effects of depth- and $\mathrm{CO}_{2}$-dependent $\mathrm{C}: \mathrm{N}$ ratios of particulate organic matter (POM) on the marine carbon cycle, Global Biogeochem. Cycles, 18, GB2015, doi:10.1029/2003GB002184.

Shi, D., Y. Xu, B. Hopkinson, and F. M. M. Morel (2010), Effect of ocean acidification on iron availability to marine phytoplankton, Science, 327, 676-679, doi:10.1126/science.1183517. 
Steinacher, M., et al. (2010), Projected 21st century decrease in marine productivity: A multi-model analysis, Biogeosciences, 7, 979-1005, doi:10.5194/bg-7-979-2010.

Takahashi, T., W. Broecker, and S. Langer (1985), Redfield ratio based on chemical data from isopycnal surfaces, J. Geophys. Res., 90(C4), 6907-6924, doi:10.1029/JC090iC04p06907.

Takahashi, T., et al. (2009), Climatological mean and decadal change in surface ocean $\mathrm{pCO}_{2}$ and net sea-air $\mathrm{CO}_{2}$ flux over the global oceans, Deep Sea Res., Part II, 56, 554-577, doi:10.1016/j.dsr2.2008.12.009.

Tanaka, T., et al. (2008), Availability of phosphate for phytoplankton and bacteria and of glucose for bacteria at different $\mathrm{pCO}_{2}$ levels in a mesocosm study, Biogeosciences, 5, 669-678, doi:10.5194/bg-5-669-2008.

Thingstad, T. F., et al. (2008), Counterintuitive carbon-to-nutrient coupling in an Arctic pelagic ecosystem, Nature, 455, 387-390, doi:10.1038/ nature 07235 .

Timmermans, K. R., B. van der Wagt, and H. J. W. de Baar (2004), Growth rates, half saturation constants, and silicate, nitrate, and phosphate deple- tion in relation to iron availability of four large open ocean diatoms from the Southern Ocean, Limnol. Oceanogr., 49(6), 2141-2151, doi:10.4319/ 1o.2004.49.6.2141.

Tortell, P. D et al (2002), $\mathrm{CO}_{2}$ effects on taxonomic composition and nutrient utilization in an equatorial Pacific phytoplankton assemblage, Mar. Ecol. Prog. Ser., 236, 37-43, doi:10.3354/meps236037.

Tortell, P. D., et al. (2008), $\mathrm{CO}_{2}$ sensitivity of Southern Ocean phytoplankton, Geophys. Res. Lett., 35, L04605, doi:10.1029/2007GL032583.

Zeebe, R. E., and D. Wolf-Gladrow (2001), $\mathrm{CO}_{2}$ in Seawater: Equilibrium, Kinetics, Isotopes, Elsevier Oceanogr. Ser., 65, 346 pp., Amsterdam.

L. Bopp, M. Gehlen, and A. Tagliabue, Laboratoire des Sciences du Climat et de l'Environnement, IPSL-CEA-CNRS-UVSQ Orme des Merisiers, F-91198, Gif sur Yvette, France. (atagliab@gmail.com) 